Research Article

\title{
The Effect of Lithium on Inflammation-Associated Genes in Lipopolysaccharide-Activated Raw 264.7 Macrophages
}

\author{
Raymond T. Makola $\mathbb{D}^{1},{ }^{1}$ Vusi G. Mbazima ${ }^{D},{ }^{1}$ Matlou P. Mokgotho ${ }^{D},{ }^{1}$ \\ Vincent S. Gallicchio, ${ }^{2}$ and Thabe M. Matsebatlela $\mathbb{D}^{1}$ \\ ${ }^{1}$ Department of Biochemistry Microbiology and Biotechnology, School of Molecular and Life Sciences, \\ University of Limpopo (Turfloop Campus), Sovenga 0727, South Africa \\ ${ }^{2}$ Department of Biological Sciences, Clemson University, Clemson, SC 29634, USA
}

Correspondence should be addressed to Thabe M. Matsebatlela; thabe.matsebatlela@ul.ac.za

Received 28 October 2019; Revised 31 January 2020; Accepted 11 May 2020; Published 25 July 2020

Academic Editor: Han J. Moshage

Copyright (C) 2020 Raymond T. Makola et al. This is an open access article distributed under the Creative Commons Attribution License, which permits unrestricted use, distribution, and reproduction in any medium, provided the original work is properly cited.

\begin{abstract}
Lithium remains the preferred Food and Drug Administration- (FDA-) approved psychiatric drug for treatment of bipolar disorders since its medical establishment more than half a century ago. Recent studies revealed a promising role for lithium in the regulation of inflammation, oxidative stress, and neurodegeneration albeit unclear about its exact mode of action. Thus, the intention of this study is to delineate the regulatory mechanisms of lithium on oxidative stress in lipopolysaccharide- (LPS-) activated macrophages by evaluating its effects on nuclear factor- $\kappa \mathrm{B}(\mathrm{NF}-\kappa \mathrm{B})$ activity and mRNA expression of multiple oxidative stress-related NF- $\kappa$ B genes. Raw 264.7 macrophages were treated with up to $10 \mathrm{mM}$ lithium, and no change in cell proliferation, viability, growth, and cell adhesion was observed in real time. Pretreatment with low doses of lithium was shown to reduce nitric oxide (NO) production in LPS-activated macrophages. A reduced internal $\mathrm{H}_{2} \mathrm{DCFDA}$ fluorescence intensity, indicative of reduced reactive oxygen species (ROS) production, was observed in LPS-activated Raw 264.7 macrophages treated with lithium. Lithium has been shown to lower the production of the chemokine RANTES; furthermore, this inhibitory action of lithium has been suggested to be independent of glycogen synthase kinase-3 $\beta$ (GSK3 $\beta$ ) activity. It is shown here that lithium modulates the expression of several inflammatory genes including I $\kappa \mathrm{B}-\alpha$, TRAF3, Tollip, and NF- $\kappa \mathrm{B} 1 / \mathrm{p} 50$ which are regulators of the NF- $\kappa \mathrm{B}$ pathway. Moreover, lithium inhibits NF- $\kappa \mathrm{B}$ activity by lowering nuclear translocation of NF- $\kappa \mathrm{B}$ in LPS-activated macrophages. This is the first study to associate Tollip, Traf-3, and I $\kappa$ B- $\alpha$ mRNA expression with lithium effect on NF- $\kappa$ B activity in LPSactivated Raw 264.7 macrophages. Although these effects were obtained using extratherapeutic concentrations of lithium, results of this study provide useful information towards understanding the mode of action of lithium. This study associates lithium with reduced oxidative stress in LPS-activated Raw 264.7 macrophages and further suggests candidate molecular targets for the regulation of oxidative stress-related diseases using lithium beyond bipolar disorders.
\end{abstract}

\section{Introduction}

Lithium is a gold standard therapeutic drug used in psychiatry for the treatment of manic depression since its establishment in 1949 [1, 2]. It is an alkali metal and a monovalent trace element known to be reactive due to its unpaired electron which contributes to its chemical reactivity [3]. Lithium regulates several major biological processes which include receptor-mediated signalling, ion transport, hormonal and circadian systems, and inflammatory signalling pathways [3]. Lithium exerts most of its effects on several bioprocesses through inhibition or activation of vital enzymes such as inhibition of inositol monophosphatase (IMPase), inositol polyphosphate 1phosphatase (IPPase), bisphosphate 3-nucleotidase (BPNT1), fructose 1,6 bisphosphate (FBPase), nuclear factor-E2 factor 2 (Nrf 2), cyclooxygenase (COX), and GSK-3 $\beta$ [4]. This enzyme inhibition/activation phenomenon is thought to be the mechanism behind lithium alteration of cell signalling pathways [5]. 
Lithium is thought to inhibit or activate some of these enzymatic activities partly due to its similar radius with enzymes cofactors such as magnesium [6]. Interference of lithium with vital inflammatory kinases and transcription factors makes it a potential candidate for regulation of chronic inflammation and oxidative stress conditions. A larger group of chronic ailments are related to or caused by dysregulation of the innate immune response and uncontrolled production of reactive oxygen species that result in oxidative stress. Oxidative stress occurs when the production of oxidants outweighs the production of antioxidants such as superoxide dismutase, glutathione peroxidase, and catalase as well as the nonenzymatic antioxidants such as glutathione and vitamins C, D, and E. Under normal physiological conditions, production of antioxidants serves as a defence mechanism that neutralises detrimental free radicals such as reactive oxygen species (ROS) and reactive nitrogen species (RNS) [7].

These ROS are normal byproducts of metabolism generated by reducing oxygen during mitochondrial electron transport chain. They are known to be less severe in trace amounts and yield beneficial properties that include wound healing and cellular signalling pathways as second messengers [7]. Most ROS are produced in excess during inflammation, the oldest known defence mechanism both phylogenetically and ontogenetically. Inflammation occurs as an immune response to an external or internal challenge by an injurious agent. It is controlled by cytokines, chemokines, products of the plasma enzyme systems, lipid mediators released from different cells and vasoactive mediators released from mast cells, basophils, platelets, and macrophages [8].

Inflammation and oxidative stress conditions emanate from persistent activation of inflammatory enzymes and transcription factors such as activator protein -1 (AP-1), NF$\kappa \mathrm{B}$, and GSK- $3 \beta[9,10]$. In other studies, lithium has been postulated to inhibit GSK- $3 \beta$ both directly through competitive inhibition that includes binding to magnesiumsensitive sites and indirectly through induced phosphorylation at serine-9/21 residue by protein kinases $C$ and $B$ $[2,11]$. Although the putative mechanism by which lithium exerts its antimanic, antidepressant, and antiapoptotic characteristics is not well known, other studies $[4,5]$ link these lithium properties with the inhibition of GSK-3. The enzyme GSK-3 is a serine-threonine kinase previously known for its role in insulin receptor signalling; however, recent findings demonstrated the broad spectrum of GSK-3 activities such as its involvement in cell growth, differentiation, apoptosis, and inflammation $[12,13]$.

GSK-3 is thought to regulate these bioprocesses through the modulation of several cell signalling pathways and activation of transcription factors and enzymes such as AP-1, cAMP response element-binding (CREB), NF- $\kappa B$, heat shock protein 1 (HSP-1), and CCAAT/enhancer binding proteins $[12,13]$. Lithium's antimanic, antidepressant, and anti-inflammatory properties mode of action remains sparse, since most of these reports emanate from neuropsychiatry experimental models [12-14]. Hence, in this study, oxidative stress related genes are investigated in the macrophage model as an attempt to further delineate its mode of action. In this study, the effects of lithium on cellular integrity and mRNA expression of genes known to play a role in inflammation and oxidative stress are investigated in LPS-activated Raw 264.7 macrophages in real time.

\section{Results}

2.1. Effects of Lithium on Morphology, Adhesion, Growth, and Viability of Raw 264.7 Cells. To evaluate the cytotoxicity profiles of lithium on Raw 264.7 macrophages, cells were treated with various lithium concentrations wherein cell viability and integrity was evaluated in real time using the MTT viability assay and xCELLigence real-time cell analyser system. Treatment of Raw 264.7 cells with $0.3125-20 \mathrm{mM}$ lithium resulted in no change in cell viability as compared to negative control; $0.02 \mathrm{mg} / \mathrm{ml}$ actinomycin-D and 50-100 mM lithium which were highly cytotoxic (Figure 1(a)). Moreover, the Raw 264.7 cells retained their morphology after treatment with lithium. As depicted in the cell images below, $\mathrm{LiCl}$ concentrations between 0.3125 and $10 \mathrm{mM}$ stimulated growth of these immune cells, which is not the case with $20 \mathrm{mM} \mathrm{LiCl}$ (Figure 1(b)). In addition, the current-based real-time cell analyser system (xCELLigence) showed that concentrations of up to $20 \mathrm{mM}$ lithium did not induce any form of cell death in Raw 264.7 cells (Figure 2(a)), whereas $50-100 \mathrm{mM}$ lithium concentrations were as cytotoxic as $0.02 \mathrm{mg} / \mathrm{ml}$ actinomycinD (Figure 2(b)). Control cells, NIH 3T3 fibroblast cells, showed similar outcomes as treated with various concentrations of lithium (results not shown).

\subsection{Effects of Lithium on Induction of Apoptosis in Raw 264.7} Macrophages. To evaluate the induction of apoptosis in macrophages, cells were treated with $10 \mathrm{mM}$ lithium for 24 hours and stained with Annexin-V-FITC and PI. Cells staining positive for Annexin-V-FITC are indicative of the presence of phosphatidylserine (PS) residues on membrane surface and early apoptosis, whereas nuclei staining positive with PI indicate loss of membrane integrity and late apoptosis. Raw 264.7 cells treated with $10 \mathrm{mM}$ lithium retained their morphology and stained negative for both Annexin- $\mathrm{V}$ and PI (Figure 3). On the other hand, cells treated with $0.02 \mathrm{mg} / \mathrm{ml}$ actinomycin-D lost their spindled shape morphology and stained positive for Annexin- $V$ but negative for PI (Figure 3). In addition to microscopic analysis of apoptotic effects of lithium, flow cytometric analysis further showed the nonapoptotic property of $10 \mathrm{mM}$ lithium (Figure 4). Untreated control, $10 \mathrm{mM} \mathrm{NaCl}$-, and $10 \mathrm{mM}$ lithium-treated cells maintained a high cell count in the negative bottom-left quadrat as shown by quadrat statistics $(92.82 \%, 87.57 \%$, and $85.49 \%$, resp.). The negative control $0.02 \mathrm{mg} / \mathrm{ml}$ actinomycin-D treatment displayed a major cell count in the upper-right $(39.35 \%)$ and a minor cell count in the bottom-right quadrat $(15.51 \%)$, thus, suggesting the onset of the late phase of apoptosis.

2.3. Lithium Inhibits Oxidative Burst in LPS-Activated Raw 264.7 Cells. The key role played by macrophages as the first line of defence and that they express important receptors 


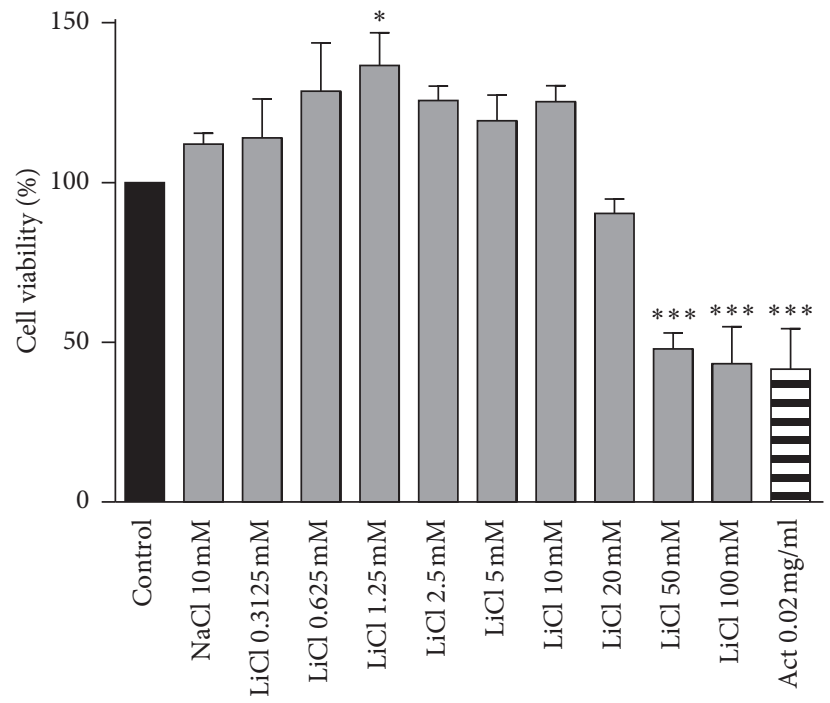

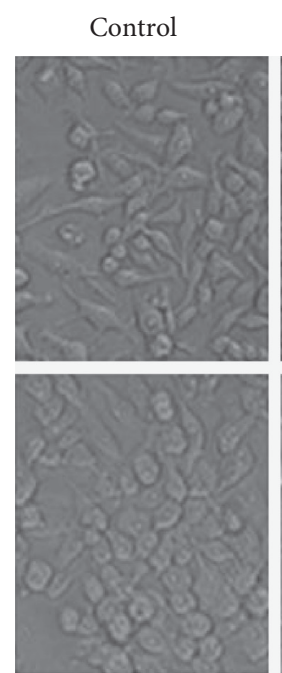

$\mathrm{LiCl} 5 \mathrm{mM}$
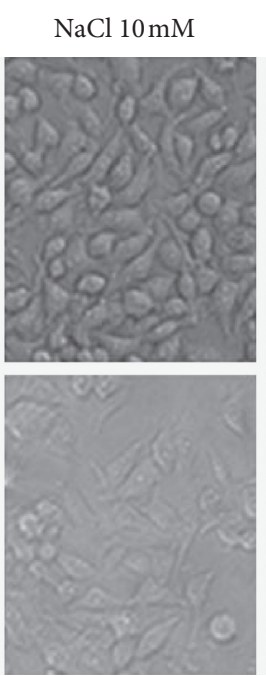

$\mathrm{LiCl} 10 \mathrm{mM}$

\begin{abstract}
$\mathrm{LiCl} 0.3125 \mathrm{mM}$
\end{abstract}
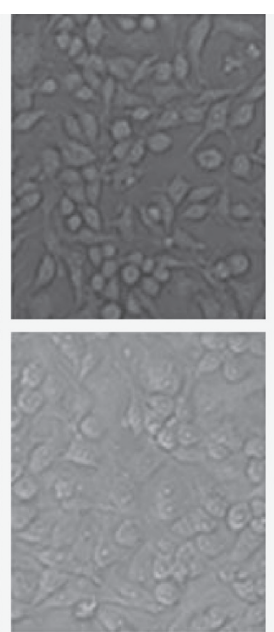

$\mathrm{LiCl} 20 \mathrm{mM}$

(a)

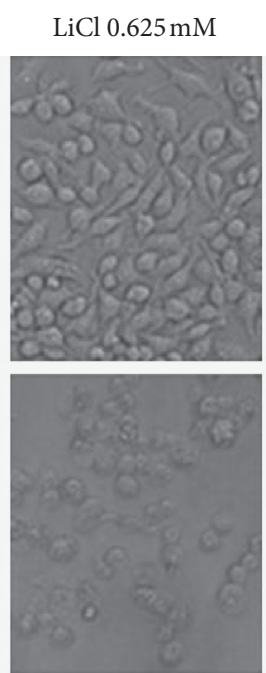

$\mathrm{LiCl} 50 \mathrm{mM}$
$\mathrm{LiCl} 1.25 \mathrm{mM}$
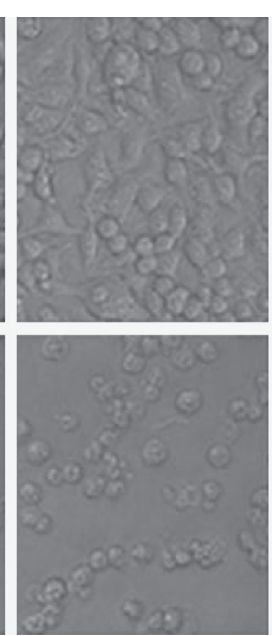

$\mathrm{LiCl} 100 \mathrm{mM}$
$\mathrm{LiCl} 2.5 \mathrm{mM}$
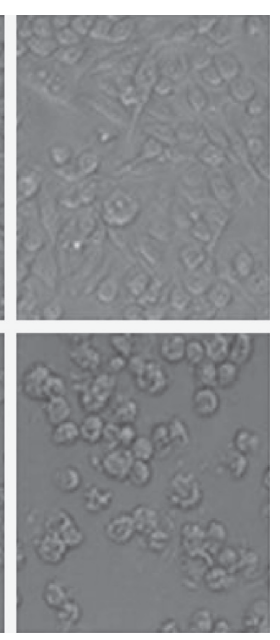

Act $0.02 \mathrm{mg} / \mathrm{ml}$

(b)

Figure 1: The effects of lithium on viability, morphology, and proliferation of Raw 264.7 macrophage cells. To examine the effects of lithium on proliferation and viability of Raw 264.7 macrophages, cells were seeded in 96 -well plates at $6 \times 10^{6}$ cells/well and treated with LiCl $(0.3125$, $0.625,1.25,2.5,5,10,2,0,50$, and $100 \mathrm{mM}), \mathrm{NaCl}(10 \mathrm{mM})$, and actinomycin-D $(0.02 \mathrm{mg} / \mathrm{ml})$ for 24 hrs. Cells were viewed and captured with the Nikon Ti-E inverted microscope (b); thereafter $5 \mathrm{mg} / \mathrm{ml} \mathrm{MTT}$ was added for $4 \mathrm{hrs}$ and then absorbance was read using by GloMaxMulti microplate reader at $570 \mathrm{~nm}$ (Promega, USA) (a). Graphs were executed using GraphPad Prism 4 software and the statistical analysis was carried out using GraphPad InStat ${ }^{\mathrm{TM}}$ software using ANOVA (Tukey-Kramer, ${ }^{*} p<0.05{ }^{* * *} p<0.001$ ).

that stimulate inflammatory signalling pathways makes this cell line a priority in this study [15]. The persistent/ undercontrolled stimulated inflammation elicits oxidative stress which is linked to the pathogenesis of a plethora chronic ailments [7], hence the use of stimulated Raw 264.7 as the model for oxidative stress. As displayed in Figure 5(a), the lower fluorescence intensity observed in Raw 264.7 cells after treatment with $10 \mathrm{mM}$ lithium suggests that lithium inhibits production of ROS in these cells. The LPS-activated Raw 264.7 cells displayed high fluorescence intensity compared to cells treated with both LPS and $10 \mathrm{mM}$ lithium. The variation in fluorescence intensity was as well shown by the measurement of fluorescence intensity using the NIS Element view imaging software (Nikon, Japan) (Figures 5(a) and 5(b)). These findings show a statistically significant difference of fluorescence intensity between cells treated with lithium alone and those treated with both lithium and LPS (Figure 5(b)). Other stimulants such as FMLP and PMA have been used in this study. The treatment of cells with lithium in the presence of those stimulants showed lowered fluorescence intensity (results are not shown). 


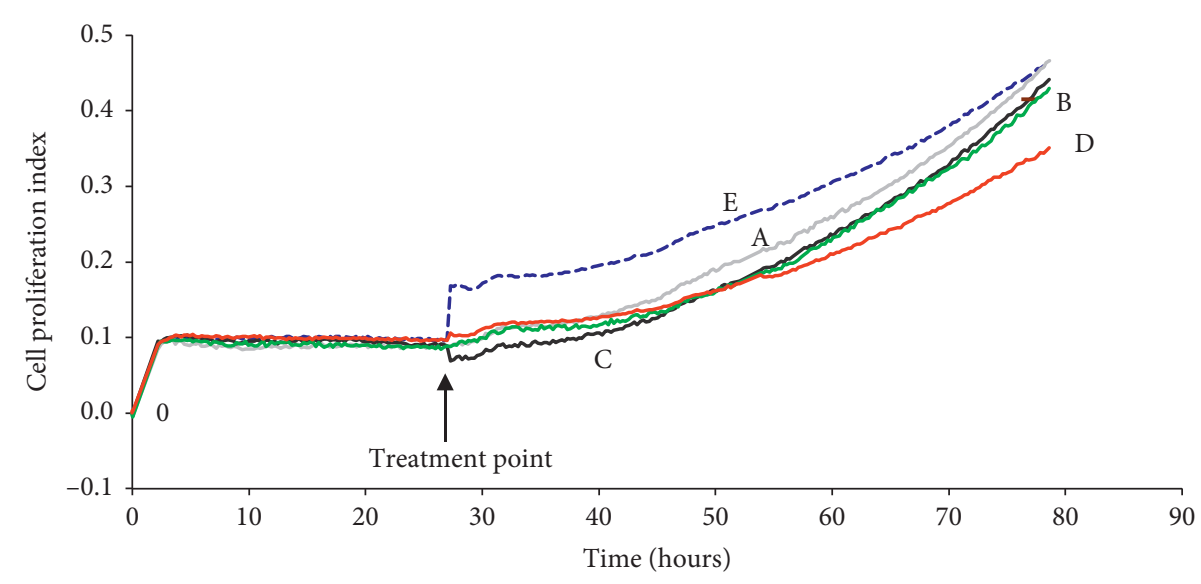

[A] $\mathrm{LiCl} 10 \mathrm{mM}$
[B] $\mathrm{LiCl} 2.5 \mathrm{mM}$
[C] $\mathrm{LiCl} 5 \mathrm{mM}$

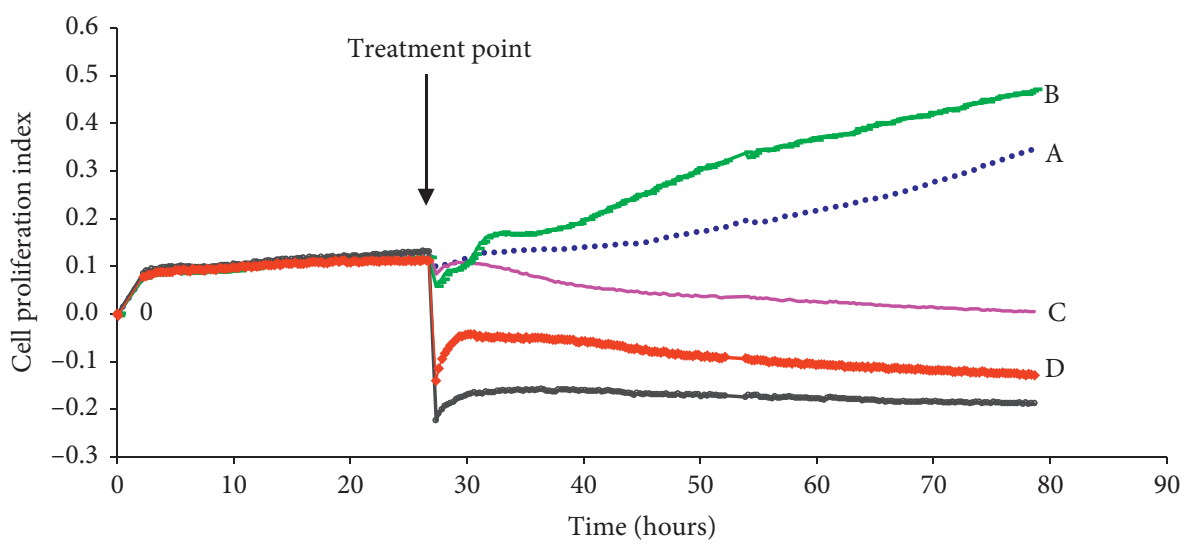

[A] Control

[B] $\mathrm{NaCl} 10 \mathrm{mM}$
[D] $\mathrm{LiCl} 1.25 \mathrm{mM}$

[E] $\mathrm{LiCl} 20 \mathrm{mM}$

(a)

[C] Actinomycin-D $0.02 \mathrm{mg} / \mathrm{ml}$
[D] LiCl $50 \mathrm{mM}$

(b)

FiguRE 2: The effect of lithium on proliferation and cellular integrity of Raw 264.7 macrophages in real time. Cells were seeded at 40,000 cell/ well in an E plate for $24 \mathrm{hrs}$ and then treated with $0.02 \mathrm{mg} / \mathrm{ml}$ actinomycin-D, $10 \mathrm{mM} \mathrm{NaCl}$, and various concentrations of lithium (1.25-20 mM (a) and 50-100 mM (b)) for 56 hrs. The xCELLigence (RTCA) software was set to take readings after every 15-minute interval giving a real-time measure of cell size, adhesion, growth, viability, and proliferation.

2.4. Effects of Lithium on LPS-Induced NO Production on Raw 264.7 Cells. Activated macrophages produce nitric oxide which has a short life-span due to its instability and volatility. Analysis of nitric oxide involves colorimetric measurement of nitrite $\left(\mathrm{NO}_{2}-\right)$, its stable and nonvolatile breakdown product [16]. Nitric oxide measure embodies levels of reactive nitrogen species (RNS). Lithium- $(1.25,2.5$, and $5 \mathrm{mM}$ ) treated cells significantly inhibited NO production in LPS-activated Raw 264.7 cells compared to untreated LPS- activated control cells. However, the $10 \mathrm{mM}$ lithium-treated cells and LPS-activated cells showed no inhibition of NO production. The same outcomes were observed in stimulated $10 \mathrm{mM} \mathrm{NaCl}$-treated cells $(p<0.05)$ (Figure 6). The findings in Figure 6 were also confirmed using a nitric oxide fluorescent probe, DAF2-DA, which showed that less than $10 \mathrm{mM}$ lithium concentrations significantly lower NO production. Low fluorescence intensity was detected in cells treated with less than $10 \mathrm{mM}$ doses of lithium and activated with LPS compared to cells activated with LPS alone. A lower fluorescence intensity was observed in LPS-activated macrophages treated with $5 \mathrm{mM}$ lithium compared to LPS-activated untreated control and NaCl-treated cells (Figures 7(a) and 7(b)).

2.5. The Effects of Lithium on Translocation of the NF- $\kappa B$ Transcription Factor in Raw 264.7 Macrophages Activated with LPS. Since NF- $\kappa \mathrm{B}$ is one of the main transcription factors involved in the regulation of inflammation and ROS/ RNS production, the effect of lithium on translocation of this transcription factor in LPS-activated macrophages was studied. Upon activation, the NF- $\kappa \mathrm{B}$ dimer (p50/p65) 


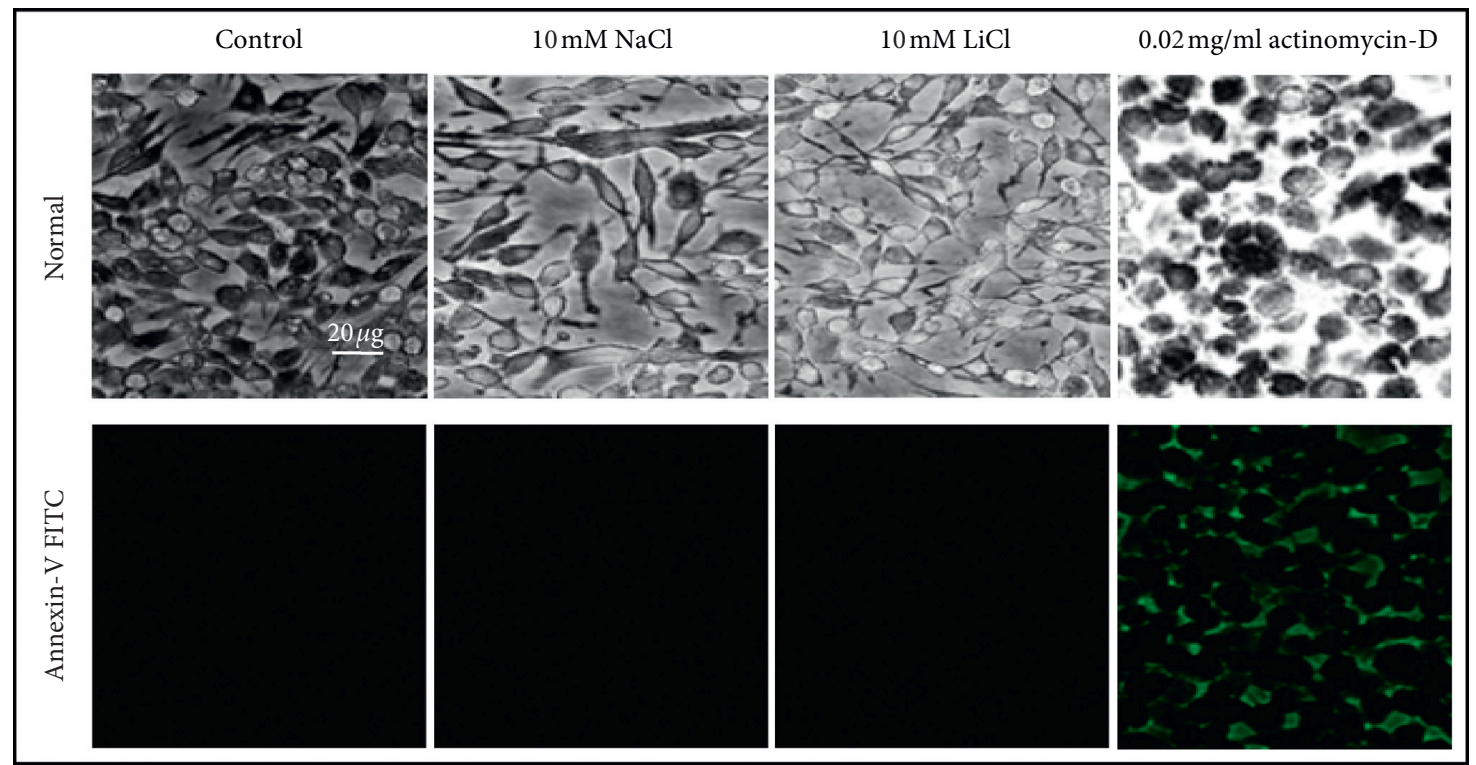

FIGURE 3: Determination of the apoptosis effect of lithium on Raw 264.7 macrophage cells using fluorescent microscopy. Cells were cultured at a density of $6 \times 10^{5}$ cell $/ \mathrm{ml}$ on coverslip in 6-well plates. Followed by treating cell with lithium $10 \mathrm{mM}, \mathrm{NaCl} 10 \mathrm{mM}$, actinomycin-D $0.02 \mathrm{mg} / \mathrm{ml}$, and untreated cell were used as control for $24 \mathrm{hrs}$. Staining with Annexin-V and PI followed for $30 \mathrm{~min}$ at RT in the dark. Thereafter, cells were fixed and mounted on the slides and then measurement of fluorescence was accomplished by capturing pictures at 20x magnification with Nikon Ti-E inverted fluorescent microscope.

translocates from the cytoplasm into the nucleus where it binds to kappa responsive site and induce transcription of several inflammatory genes. Hence, translocation of NF- $\kappa \mathrm{B}$ from cytosol to nucleus is indicative of onset of inflammation. Thus, LPS-activated Raw 264.6 macrophages were treated with lithium, and NF- $\kappa \mathrm{B}$ translocation was monitored using immunofluorescence microscopy. The position of the nuclei is marked with DAPI-staining, and the movement of the NF- $\kappa \mathrm{B}$ dimer is monitored using antibodies against NF- $\kappa \mathrm{B}$ (p65) with secondary antibodies tagged with a green fluorescent probe (FITC).

A high amount of green fluorescence was observed in the nuclei of LPS-activated macrophages showing increased presence of the NF- $\kappa \mathrm{B}$ dimer in the nucleus (Figure 8). Treatment of these activated macrophages with lithium lowered the presence of fluorescent NF- $\kappa \mathrm{B}$ in the nuclei. The results below show that lithium inhibits the translocation of the NF- $\kappa \mathrm{B}$ from the cytoplasm to the nucleus in LPS-activated Raw 264.7 macrophages. In untreated macrophages, the NF- $\kappa \mathrm{B}$ dimer is located in the cytosol as shown by a characteristic green fluorescence within the cytoplasm and a conspicuous absence of the dimer in the nuclei as overlaid with DAPI-stained nucleus position (Figure 8).

2.6. Lithium Modulates Overexpression of Inhibitory Molecules That Are Related to NF- $\kappa B$ Signalling Raw 264.7 Cells after Being LPS Activated. The real-time PCR array was used to determine the effect of lithium on mRNA expression levels of NF- $\kappa \mathrm{B}$ signalling-related genes in LPS-activated Raw 264.7 macrophages. In this experiment, changes in gene expression patterns were evaluated on NF- $\kappa \mathrm{B}$ signallingassociated genes such as NF-KB1/p50, Tollip, Traf-3, and
I $\kappa \mathrm{B}-\alpha$. Treatment of nonactivated macrophages increased mRNA expression of NF- $\kappa \mathrm{B} 1 / \mathrm{p} 50$, Tollip, and Traf- 3 genes compared to the untreated control. Lithium increased macrophage NF- $\kappa \mathrm{B} 1 / \mathrm{p} 50$ mRNA gene expression by 1.9fold, Tollip levels were increased 2 -fold, and a 4 -fold increase in Traf-3 mRNA level was observed as compared to the untreated controls. Although a 4.5 -fold increase in I $\kappa \mathrm{B}$ $\alpha$ expression was observed in LPS-activated Raw 264.7 macrophage cells treated with $10 \mathrm{mM}$ lithium, a 1.5-fold decrease in $\mathrm{I} \kappa \mathrm{B}-\alpha$ mRNA levels was observed in nonactivated macrophages treated with the same concentration of lithium (Figures 9 and 10). In LPS-activated macrophages, mRNA expression of NF- $\kappa \mathrm{B} 1 / \mathrm{p} 50$, Tollip, Traf- 3 , and $\mathrm{I} \kappa \mathrm{B}-\alpha$ increased by $1.9,1.0,1.5$, and 1.8 -fold, respectively. When LPS-activated macrophages were treated with lithium, mRNA expression of NF- $\kappa \mathrm{B} 1 / \mathrm{p} 50$ increased more than 3fold, Tollip levels increased by 1.8-fold, Traf-3 levels increased by 2.4 -fold, and I $\kappa \mathrm{B}-\alpha$ mRNA levels increased by more than 4 -fold compared to the untreated macrophages (Figures 9 and 10).

2.7. Lithium Inhibition Effect on the Production of Inflammatory Mediators Is Independent of GSK3 $\beta$. Previous work links GSK3 to the regulation of the production of inflammatory mediators [9]. Thus, ROS and CCL-5 production assays (Figures 11(a) and 11(b)) were aimed at determining if lithium inhibits the production of these inflammatory molecules through GSK3 or through the inhibition of other enzymes. The SB216763 compound has been widely demonstrated to inhibit GSK-3 $\beta$ activity in both in vitro and in vivo models $[17,18]$. In Raw 264.7 macrophage cells, $10 \mu \mathrm{M}$ SB216763 was previously shown to inhibit GSK-3 $\beta$ activity 


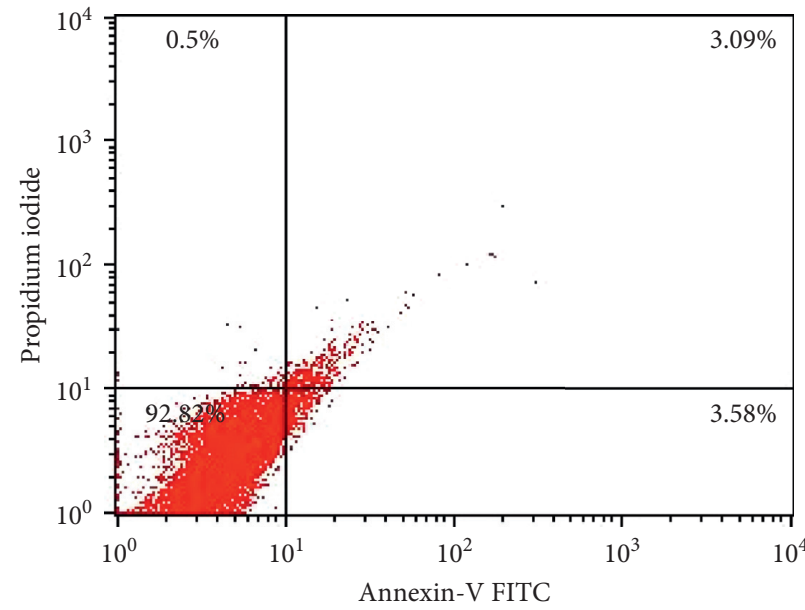

(a)

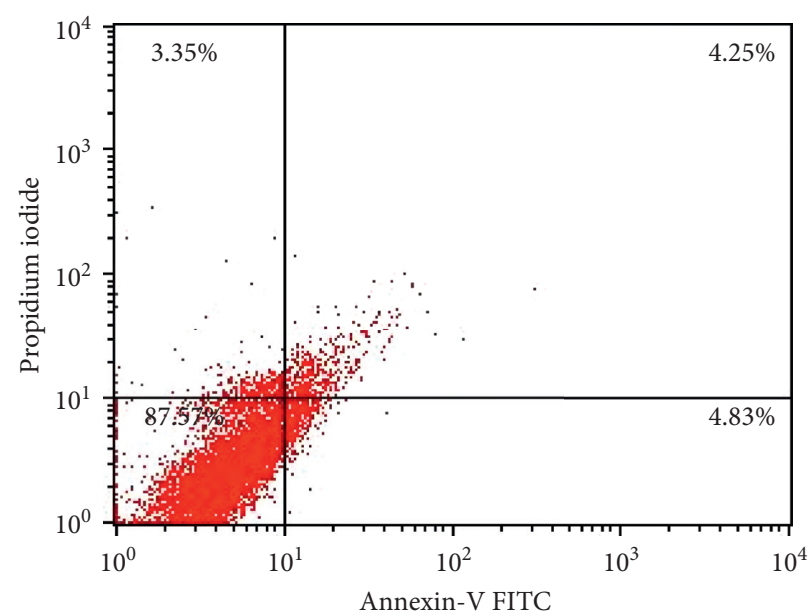

(c)

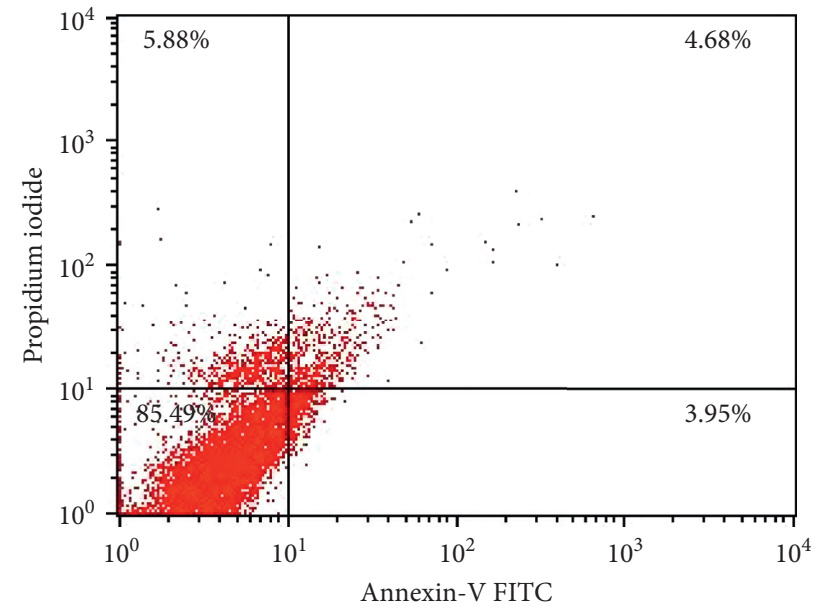

(b)

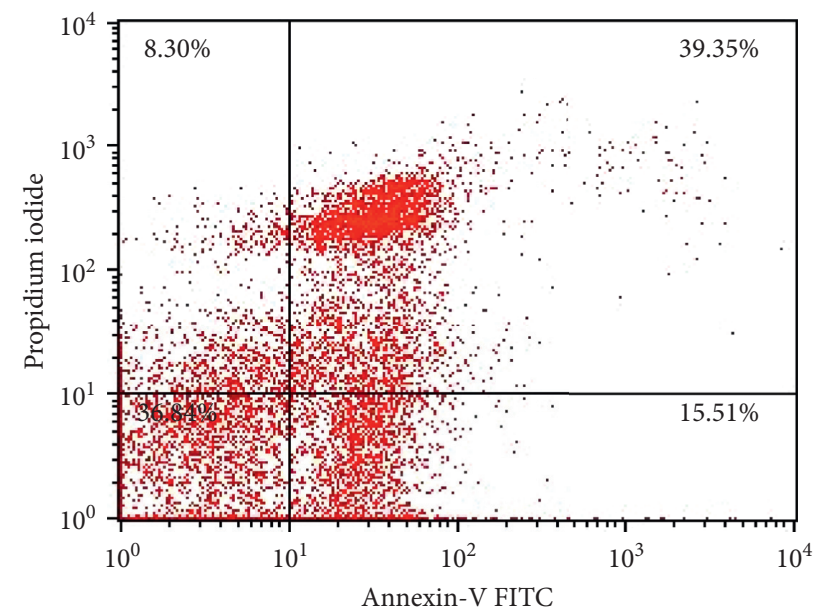

(d)

Figure 4: Determination of apoptotic properties shown by lithium on Raw 264.7 macrophage cells using flow cytometry. Apoptosis investigation was carried out by seeding cells at a concentration of $6 \times 10^{6}$ cells $/ \mathrm{ml}$ overnight in a $200 \mathrm{~mm}$ dish. This was then followed by treating the cells with 5, 10,20, and $50 \mathrm{mM}$ lithium, $10 \mathrm{mM} \mathrm{NaCl}$, and 0.01 and $0.02 \mathrm{mg} / \mathrm{ml}$ actinomycin-D for 24 hrs. Cells were thereafter stained with mixture of binding buffer, Annexin-V FITC, and PI for $20 \mathrm{~min}$ in the dark, and then cell analysis was carried out using flow cytometer (BD Biosciences, USA) according to the manufacturer's protocol. (a) Untreated control. (b) $\mathrm{LiCl} 10 \mathrm{mM}$. (c) $\mathrm{NaCl} 10 \mathrm{mM}$. (d) Actinomycin-D $0.02 \mathrm{mg} / \mathrm{ml}$.

[19]. $\mathrm{H}_{2}$ DCF-DA serves as a probe used to detect levels of ROS production, and a low fluorescence intensity was observed in cells treated with $10 \mathrm{mM} \mathrm{LiCl}$ and activated with $5 \mathrm{mg} / \mathrm{ml} \mathrm{LPS}$ compared to the untreated $5 \mathrm{mg} / \mathrm{ml}$ LPS-activated cells. This inhibition phenomenon was not observed in cells that were treated with $10 \mu \mathrm{M}$ SB216763 and activated with $5 \mathrm{mg} / \mathrm{ml} \mathrm{LPS}$. Cells treated with $10 \mathrm{mM} \mathrm{NaCl}$ and $5 \mathrm{mg} / \mathrm{ml} \mathrm{LPS} \mathrm{did} \mathrm{not}$ display any lowering of the fluorescence intensity (Figures 11(a)). The CCL-5 Elisa assay showed similar findings. Cells treated with lithium displayed lowered production of the CCL-5/RANTES chemokine (Figures 11(b)). There was no inhibition in the production of CCL-5 in cells treated with $10 \mu \mathrm{M}$ SB216763 and activated with $5 \mathrm{mg} / \mathrm{ml}$ LPS. Moreover, $10 \mu \mathrm{M}$ SB216763 did not show abrogation of inhibitory properties of lithium on the production of CCL-5, since combination of lithium and SB216763 did not show any changes in inhibition of CCL-5. A combination of results from these experiments suggests that inhibition of inflammatory mediators by lithium may be independent of GSK3 $\beta$.

\section{Discussion}

Pathogen recognition receptors (PRR) such as Toll-like receptors (TLRs) and interleukin-1 receptor type I (IL-1RI) expressed by the macrophages are central to mediating inflammatory processes. Macrophages play a crucial role as the first line of defence and create a link between innate and adaptive immune responses [15, 20]. Undercontrolled inflammatory response has been suggested to contribute to the pathogenesis of a number of ailments [7]; thus this work focused on the TLR-4-mediated NF- $\kappa$ B signalling pathway. This is the first study to show that lithium regulates mRNA expression of $\mathrm{I} \kappa \mathrm{B}-\alpha$, TRAF3, Tollip, and NF- $\kappa \mathrm{B} 1 / \mathrm{p} 50$ while inhibiting oxidative stress in LPS-activated Raw 264.7 

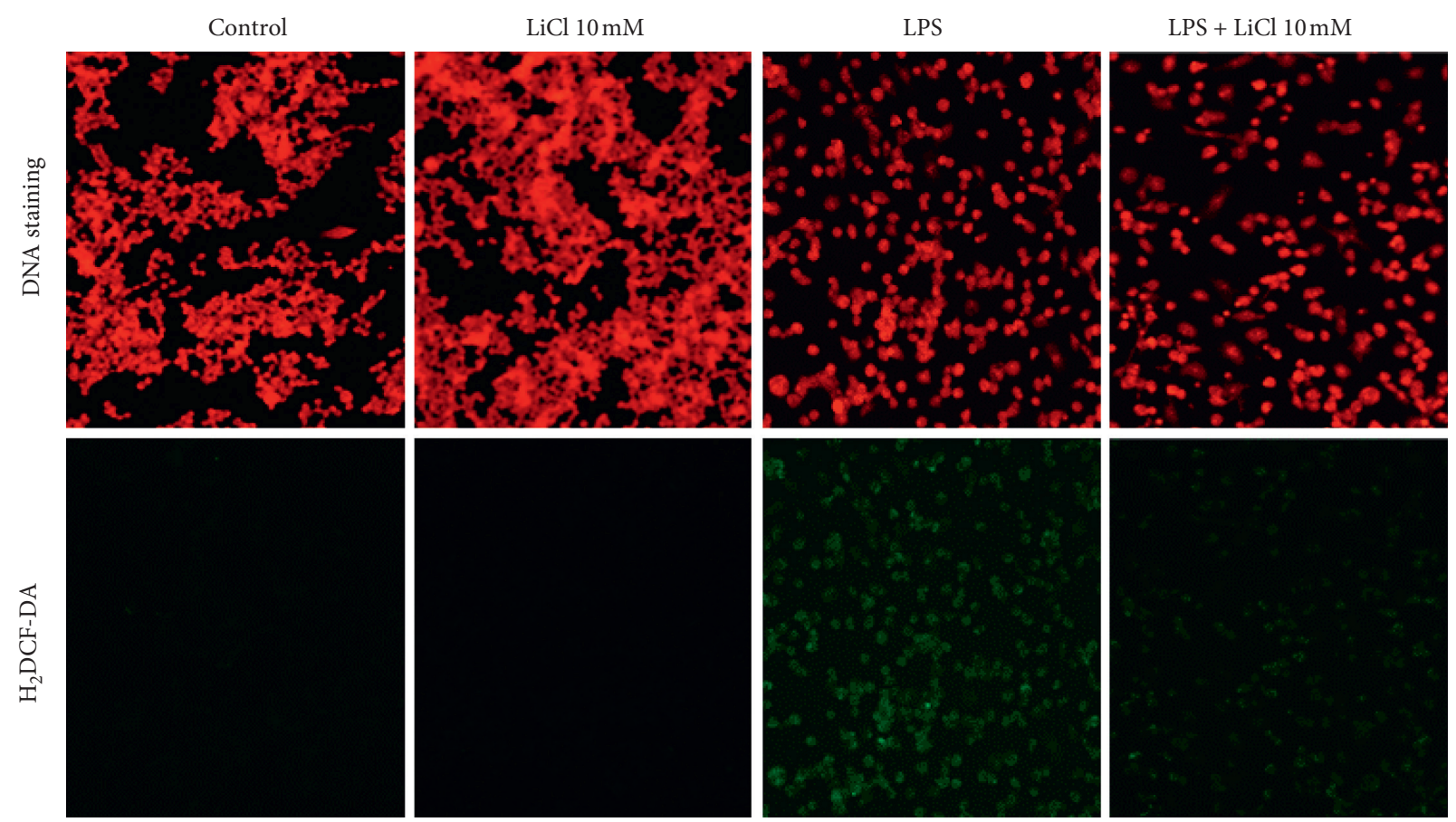

(a)

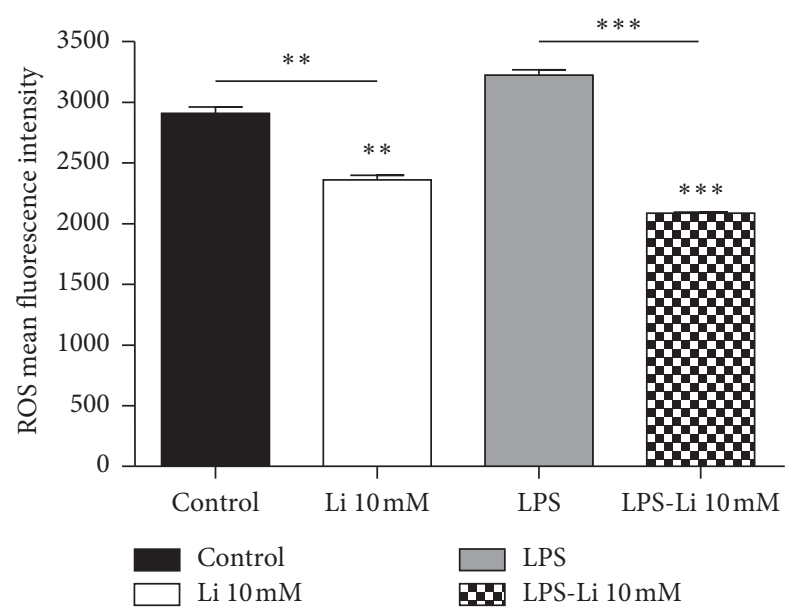

(b)

FIGURE 5: Effect of lithium on oxidative burst activated by LPS on Raw 264.7 macrophage cells. Cells were seeded at a density of $6 \times 10^{5}$ cells/ $\mathrm{ml}(200 \mu \mathrm{l})$ on a coverslip and pretreated with $10 \mathrm{mM}$ lithium and treated with $10 \mu \mathrm{g} / \mathrm{ml} \mathrm{LPS}$ for $24 \mathrm{hrs}$. The fluorescence measurement was accomplished with inverted fluorescent microscope Nikon Ti-E at 10x magnification (a). Fluorescence intensity of the pictures was measured using the NIS Element view imaging software at 10x magnification (Nikon, Japan). Graphs were executed using GraphPad Prism 4 software and the statistical analysis was carried with GraphPad InStat software using ANOVA (Tukey-Kramer) $\left({ }^{*} p<0.05 ;{ }^{* * *} p<0.001\right)$.

macrophages. The present study shows that lithium inhibits NO production, suppresses oxidative burst, and blocks NF$\kappa \mathrm{B}$ nuclear translocation, thereby maintaining cell integrity and viability at doses not higher than $20 \mathrm{mM}$.

Using fluorescence-based cellular assays, lithium is shown to inhibit production of ROS and RNS in LPSactivated macrophages. Cell-based photographic images, flow cytometry, and real-time-based cellular assays are used to effectively present visual evidence that lithium exerts its anti-inflammatory effects in these activated macrophages without inducing detrimental morphological pressure or cell death. Although concentrations of lithium above $20 \mathrm{mM}$ were used in various in vitro models [21, 22], this study has considered limiting concentrations of $\mathrm{LiCl}$ to $10 \mathrm{mM}$, since this has been demonstrated (Figure 1(a)) to be the highest lithium concentration with no effect on Raw 264.7 cell proliferation [20]. Although previous studies have suggested the narrow spectrum of action/ activity shown by lithium at therapeutic concentrations (0.4-2.0 mM LiCl) [2, 23], this work, along with other studies performed at extratherapeutic dosages [24-26], explored the effects of lithium above those concentration 


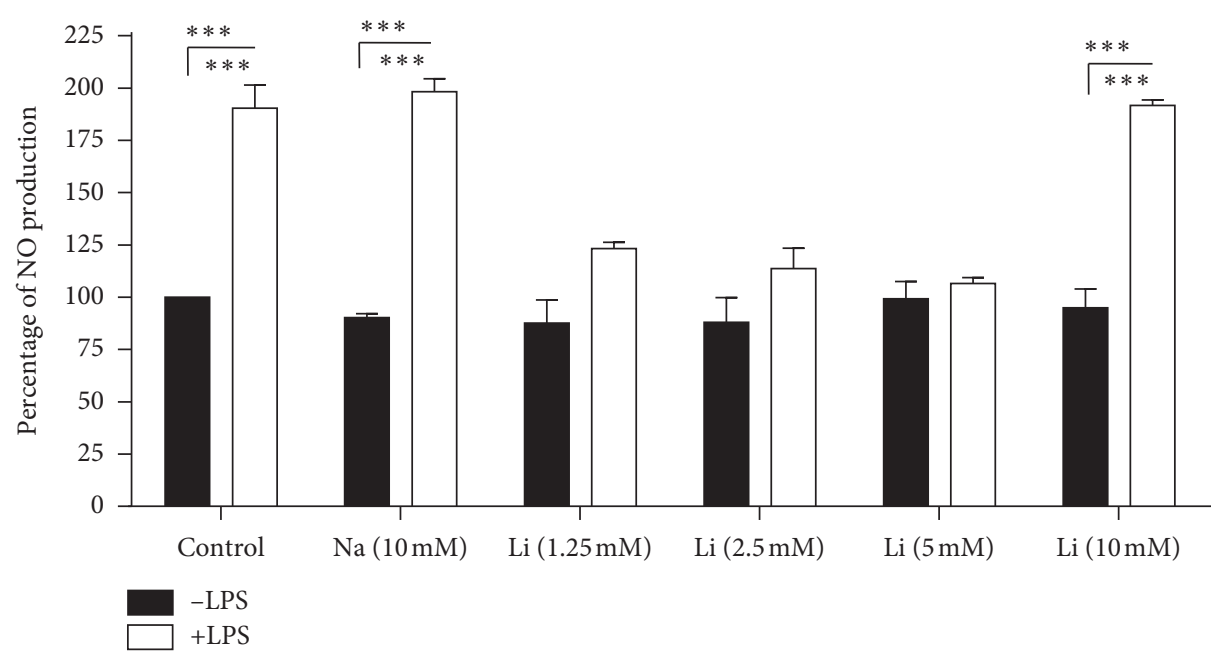

Figure 6: Effect of lithium on nitric oxide (NO) production assessed using Griess reagent on LPS-activated Raw 264.7 cells. Cells were seeded at a density of $6 \times 10^{6}$ cells $/ \mathrm{ml}$ and treatment was executed by pretreating with $10 \mathrm{mM} \mathrm{NaCl}$ and lithium $(1.25,2.5,5$, and $10 \mathrm{mM})$ for an hour thereafter; other set of wells that are already treated with lithium and $\mathrm{NaCl}$ were stimulated with $10 \mu \mathrm{g} / \mathrm{ml} \mathrm{LPS} \mathrm{for} 24 \mathrm{hrs}$. Quantitation of NO production was carried out by GloMax-Multi microplate at $550 \mathrm{~nm}$ (Promega, USA). Treatments that encompass various concentrations of lithium and $10 \mathrm{mM} \mathrm{NaCl}$ combined with LPS were compared with LPS activated wells. Graphs were executed using GraphPad Prism 4 software and the statistical analysis was carried out using GraphPad InStat software and ANOVA (Tukey-Kramer) $\left({ }^{*} p<0.05 ;{ }^{* * *} p<0.001\right)$.

limits so as to provide substantive molecular data on inflammation beyond the narrow spectrum.

This work presents NF- $\kappa \mathrm{B}$ as the main ROS and RNS regulator whose activity is inhibited by lithium possibly through gene modulation of its associate NF- $\kappa \mathrm{B}$ inhibitors: I $\kappa \mathrm{B}-\alpha$, TRAF3, Tollip, and NF- $\kappa \mathrm{B} 1 / \mathrm{p} 50$. Figure 12 stipulates the sequence of events in NF- $\kappa \mathrm{B}$ signalling pathway and lithium targeted proteins. Overexpression of Tollip impairs IL-1RI-, TLR2-, and TLR4-triggered NF- $\kappa$ B and JNK signalling pathways. Tollip binds the activated IL-1RI complex, as well as TLR2 and TLR4 complexes. Tollip also interacts with IL-1R-associated kinase 1 (IRAK-1) prior to stimulation and suppresses IRAK-1 kinase activity [27]. This has led to the concept that a Tollip-mediated pathway is required to maintain immune cells in a quiescent state in the absence of infection and facilitate the termination of IL-1R- and TLR-induced signalling during inflammation via suppression of IRAK-1 activity $[24,27]$.

The onset of inflammation in LPS-activated macrophages is initiated by binding of LPS to TLR4 [28]. Thus, lithium could be inhibiting inflammation in LPS-activated macrophages by upregulating the expression of Tollip which would then suppress TLR4-triggered NF- $\kappa \mathrm{B}$ and JNK signalling pathways. Wang and colleagues have shown that inhibitory properties of lithium on IFN- $\beta$ production in TLR3/4 and RIG-I-receptors mediated signalling which is suggested to involve the inhibition of TBK1, which could be the upstream inhibition of IRAK-1 by Tollip [20]. Moreover, this study suggests that the inflammatory influence shown by lithium is independent of GSK $3 \beta$, as Figures $11(\mathrm{a})$ and $11(\mathrm{~b})$ show that the GSK3 $\beta$ inhibitor, SB216763, has no inhibitory effects on ROS and RANTES production. This study correlates with other studies showing that lithium's influence on production of inflammatory mediators is independent of $\operatorname{GSK} 3 \beta[15,20]$.

The process used by different receptors in mediating activation of the noncanonical NF- $\kappa \mathrm{B}$ signalling pathway remains unclear. The TNFR-associated factor (TRAF) proteins may play an important role, since they are known to be recruited to various TNFR family members. Interestingly, a common TRAF molecule recruited by the different noncanonical NF- $\kappa \mathrm{B}$-stimulating receptors is TRAF3 [29]. TRAF3 is a negative regulator of NF-kappa-B-inducing kinase (NIK), a key signalling molecule involved in noncanonical NF- $\kappa$ B activation. TRAF3 physically interacts with NIK and targets NIK for degradation by the proteasomes. Remarkably, the receptor-mediated activation of noncanonical NF- $\kappa \mathrm{B}$ signalling is associated with persistent degradation of TRAF3 and the marked elevation of NIK expression [14, 29]. Findings in the present study suggest that inhibition of NF- $\kappa$ B signalling could involve upregulation of TRAF3 by lithium which would set up NIK for TRAF3-mediated destruction and result in inhibition of inflammation.

Inflammation triggered by LPS-TLR4 interaction culminates in activation of the NF- $\kappa \mathrm{B}$ pathway through dimerization of the $\mathrm{p} 65$ and p50 NF- $\kappa \mathrm{B}$ subunits. NF-kappa B is an important activator of immune and inflammatory response genes. NF-kappa B is sequestered in the cytoplasm of nonstimulated cells through interaction with the I $\kappa \mathrm{B}-\alpha$ inhibitors. These inactive complexes dissociate in response to a variety of extracellular signals, thereby allowing free NFkappa $B$ dimers to translocate to the nucleus and activate transcription of specific target genes. Phosphorylation of $\mathrm{I} \kappa \mathrm{B}-\alpha$ is responsible for dissociation of the inactive complexes, an event that is rendered irreversible by rapid $\mathrm{I} \kappa \mathrm{B}$ degradation. Inhibitor of kappa B- $\alpha$ is known to block the 


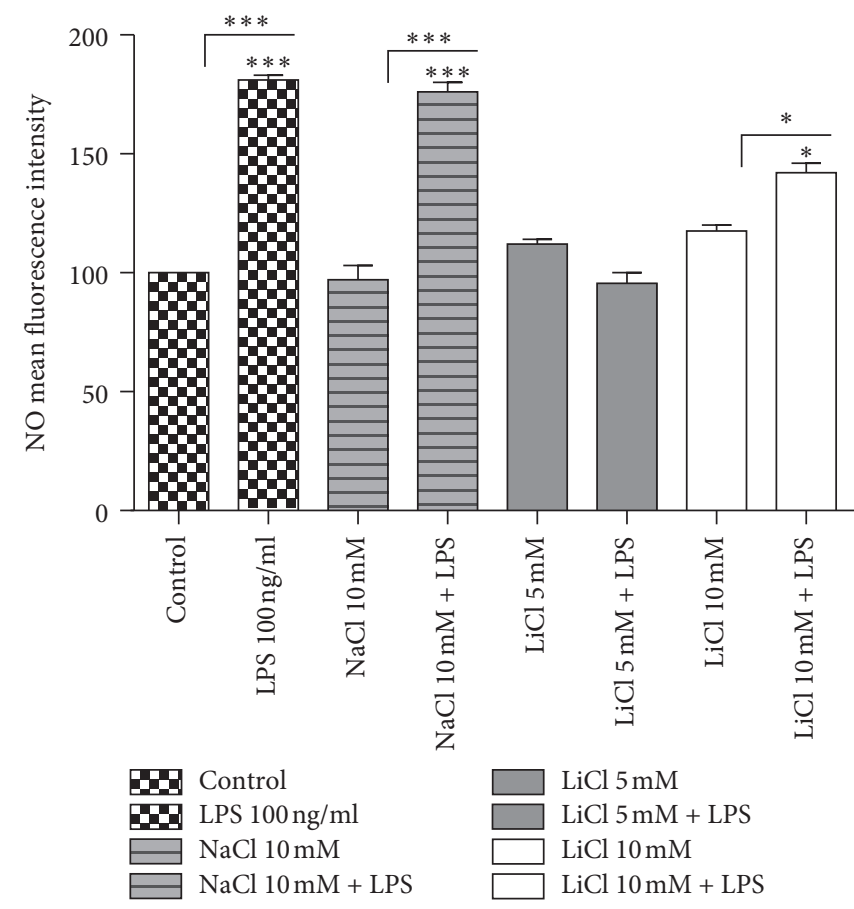

(a)
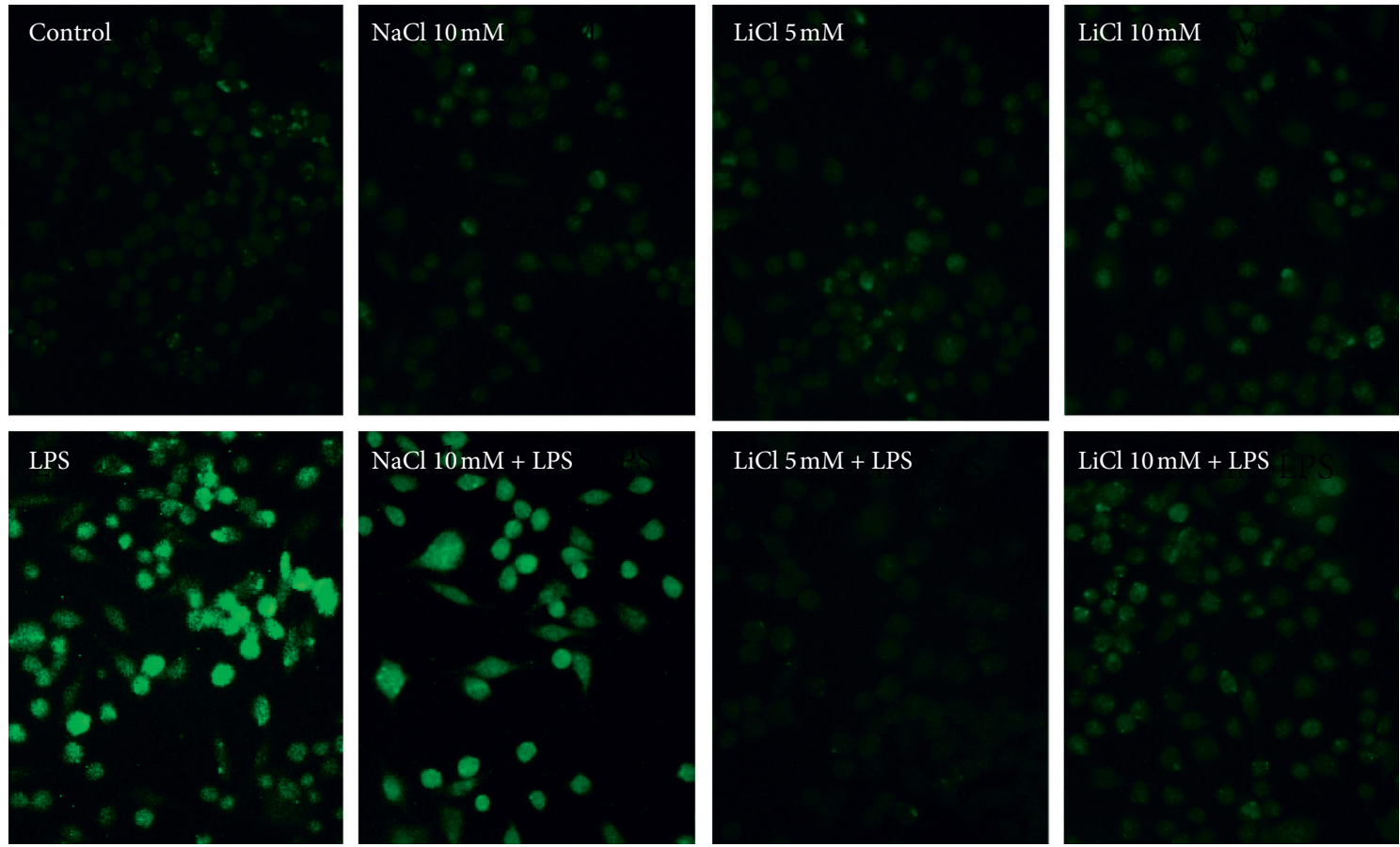

(b)

FIGURE 7: Determination of effect of lithium on nitric oxide production on LPS-induced Raw 264.7 cells. Cells were seeded at $6 \times 10^{6}$ cell $/ \mathrm{ml}$ and treated with lithium ( 5 and $10 \mathrm{mM}$ ), $10 \mathrm{mM} \mathrm{NaCl}$, and $100 \mathrm{ng} / \mathrm{ml}$ LPS, combining each of the chemicals with LPS for $24 \mathrm{hrs}$. Cells were stained with DAF2-DA and Hoechst for $20 \mathrm{~min}$ at RT. The measurement of the fluorescence was accomplished by using fluorescent inverted Nikon Ti-E microscope at 20x magnification (b). Fluorescence intensity of the pictures was measured using the NIS Element view imaging software (Nikon, Japan) (a). Graphs were executed using GraphPad Prism 4 software and the statistical analysis was carried out using GraphPad InStat software and ANOVA (Tukey-Kramer) $\left({ }^{*} p<0.05 ;{ }^{* * *} p<0.001\right)$. 

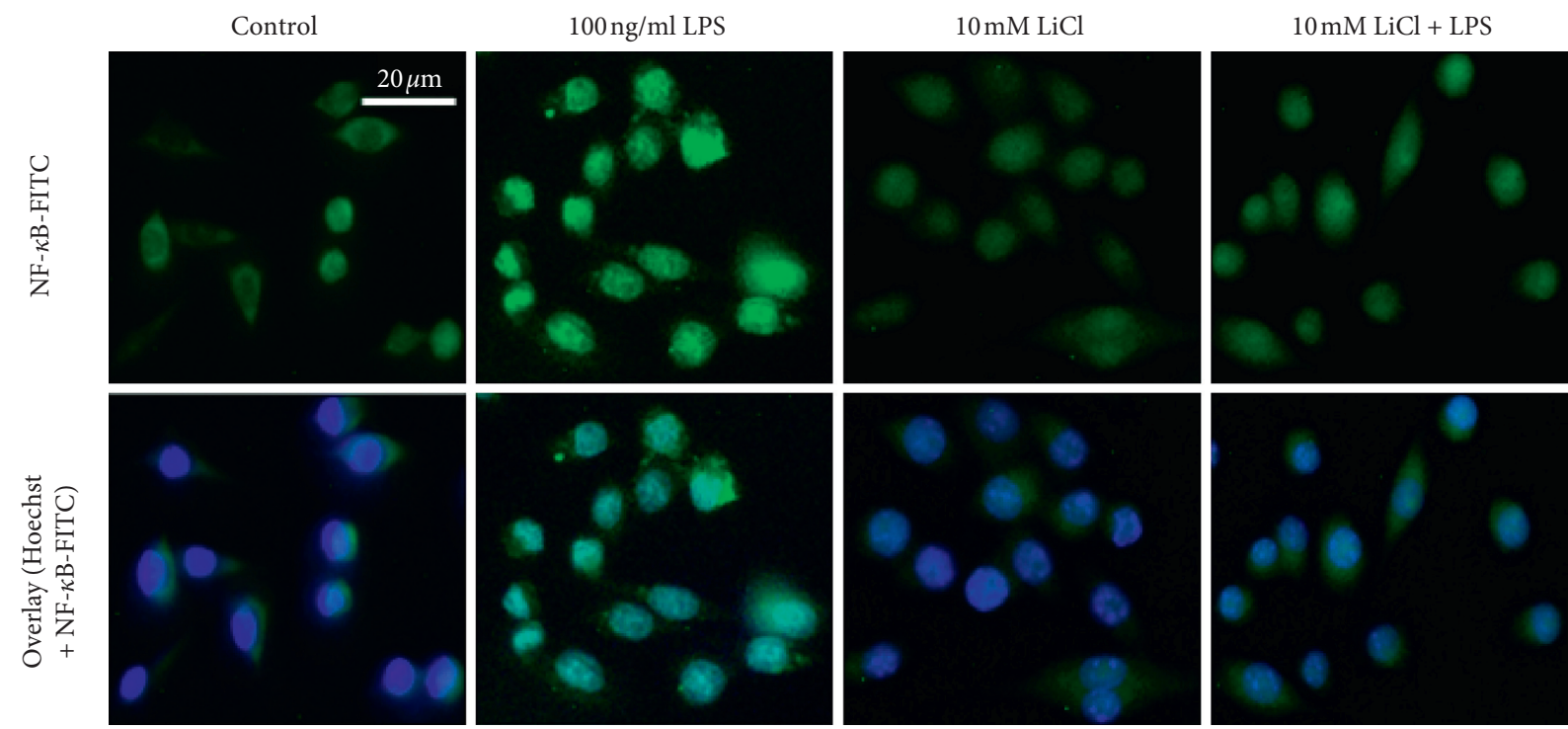

FIGURE 8: Evaluation of the effects of lithium on nuclear translocation of NF- $\kappa$ B after LPS activation of Raw 264.7 cells. Cells were cultured at a density of $2 \times 10^{5}$ cells $/ \mathrm{ml}$ on coverslips and treated with $10 \mathrm{mM}$ lithium, $10 \mathrm{mM} \mathrm{NaCl}, 100 \mathrm{ng} / \mathrm{ml}$ ultrapure LPS, and a combination of salts and LPS for $90 \mathrm{~min}$. Cells were then fixed with 3.7\% paraformaldehyde and thereafter semipermeabilised with $0.1 \%$ Triton-X100 in $1 \%$ BSA for $30 \mathrm{~min}$. The nonspecific binding was blocked for an hour with 1\% BSA and then anti-NF- $\kappa$ B antibody $(1: 500)$ was added for an hour, and then the cells were washed $3 \mathrm{x}$ with $1 \mathrm{x}$ PBS and stained for $30 \mathrm{~min}$ with anti-rabbit IgG-FITC $(1: 2000)$. After 30 min incubation, cells were washed, followed by DNA staining with $25 \mu \mathrm{g} / \mathrm{ml}$ Hoechst for $20 \mathrm{~min}$. Thereafter, coverslips were mounted on glass slides with mounting medium and then NF-kB was analysed and photographed under fluorescence inverted microscope (Nikon Eclipse TS100F, Japan).

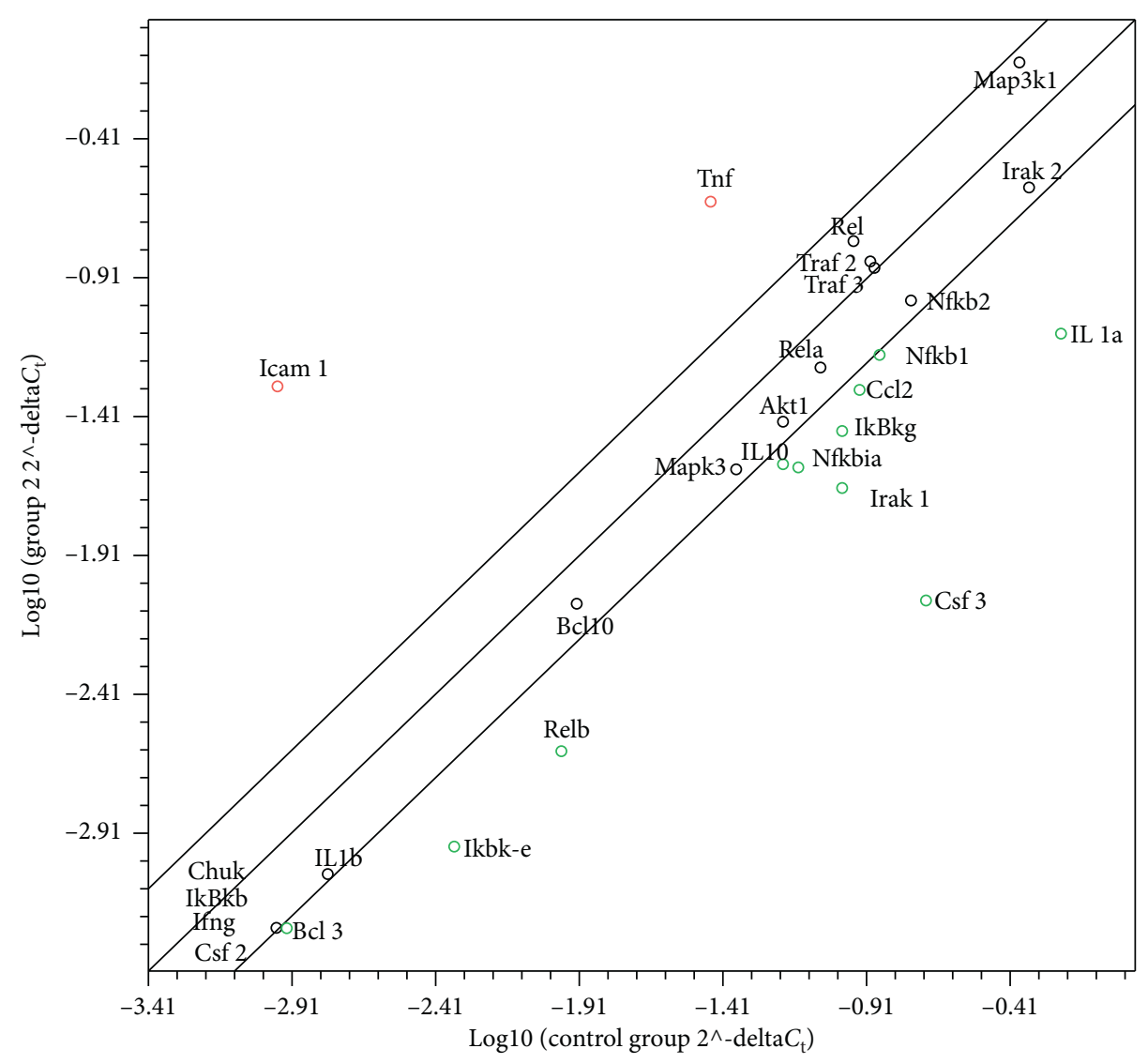

(a)

Figure 9: Continued. 


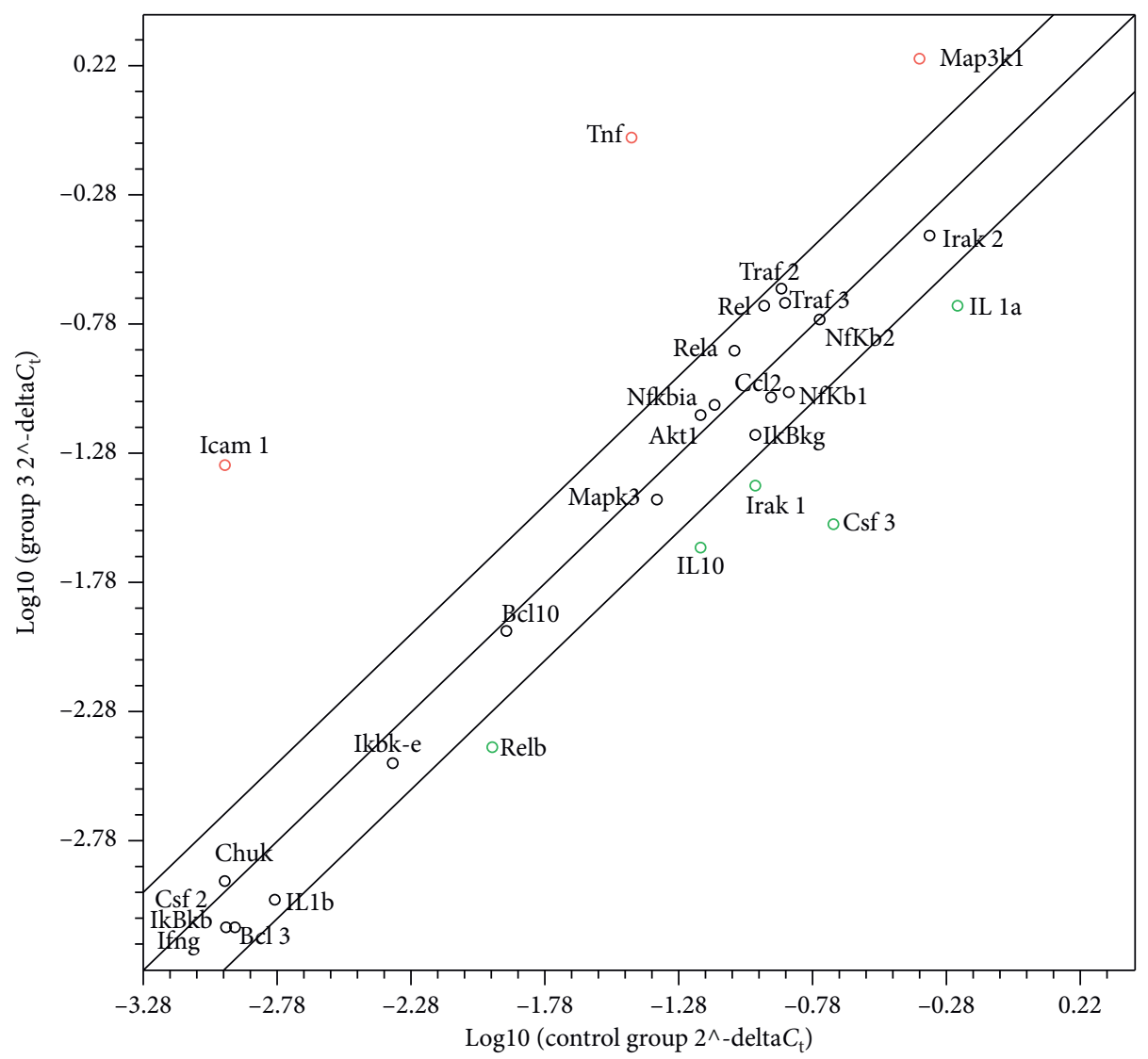

(b)

FiguRE 9: The expression pattern of NF- $\kappa$ B signalling-related genes on Raw 264.7 cells activated with LPS. Cells were cultured in 60 mm cell culture dishes overnight at a density of $6 \times 10^{6} \mathrm{cell} / \mathrm{ml}$. Thereafter, cells were treated with $10 \mathrm{mM}$ lithium, $10 \mu \mathrm{m} / \mathrm{ml} \mathrm{LPS}$, and a combination of lithium with LPS for 24 hrs. Total RNA isolation was accomplished with Qiagen Total RNA isolation kit; cDNA was synthesised with RT ${ }^{2}$ first-strand kit. RT ${ }^{2}$ profiler PCR arrays were used to measure the expression profiles of NF- $\kappa$ B in which 40 cycles where accomplished, 1 cycle for $10 \mathrm{~min}$ at $95^{\circ} \mathrm{C}$ and 40 cycles of $15 \mathrm{~s}$ at $95^{\circ} \mathrm{C}$ and $1 \mathrm{~min}$ at $60^{\circ} \mathrm{C}$. Thereafter, Qiagen web-based data analysis was used to analyse the $C_{\mathrm{t}}$ values and generate the dot plots. (a) LPS vs. control. (b) Li-LPS vs. control.

DNA-binding activity of NF- $\kappa \mathrm{B}$ p65-p50 using its DNA dissociation abilities embedded on its C-terminal [30]. In addition to $\mathrm{I} \kappa \mathrm{B}-\alpha$, the $\mathrm{p} 50$ homodimer is documented to inhibit the transcriptional role of p50-p56 heterodimer since it possesses the DNA binding domain and not the transcriptional activation domain. It is, therefore, thought to block the kappa responsive site [31]. The observation made in this current study is that lithium upregulates p50 and $\mathrm{I} \kappa \mathrm{B}$ $\alpha$ mRNA expression (Figures 9 and 10) and inhibits translocation of NF- $\kappa \mathrm{B}$ from cytosol to the nucleus (Figure 8 ). Upregulation of these $\mathrm{NF}-\kappa \mathrm{B}$ regulators could be responsible for lithium-mediated inhibition of inflammation or oxidative stress in these activated macrophages.

Translocation of NF- $\kappa$ B to the nucleus leads to DNAbinding and transcription of several inflammatory target sites. One of these target sites in macrophages is inducible nitric oxide synthase (iNOS), which is responsible for NO production. Transcription of iNOS and oxidative stress genes has been reported to be involved in the pathogenesis of a number of diseases and disorders [28]. Oxidative stress results in oxidation of proteins, lipids, and nucleic acids that eventually evoke malfunctioning cells and cell demise, leading to diseases and disorders [7]. This study suggests that the anti-inflammatory properties of lithium in LPS-activated Raw 264.7 macrophage cells could be attributed to the observed inhibition of ROS and RNS production. In this study, the florigenic cell permeant, $\mathrm{H}_{2} \mathrm{DCF}-\mathrm{DA}$, is converted to a highly fluorescent DCF through removal of the acetate groups by intracellular esterases, leading to oxidation by ROS. Results from this assay suggest that the treatment of Raw 264.7 macrophages with lithium downregulates LPSmediated ROS production. This is illustrated by the low fluorescence intensity observed in macrophage cells challenged with both lithium and LPS-activated cells in contrast to cells treated with LPS alone (Figure 5). This observation is in agreement with results observed in recent studies obtained from the treatment of glia cells and cancer cells with lithium $[24,32]$.

Lithium concentrations from 1.25 to $5 \mathrm{mM}$ showed a significant downregulation of NO production in Raw 264.7 macrophage cells. Cells activated with LPS and treated with 1.25 to $5 \mathrm{mM}$ lithium have shown low production of pink 


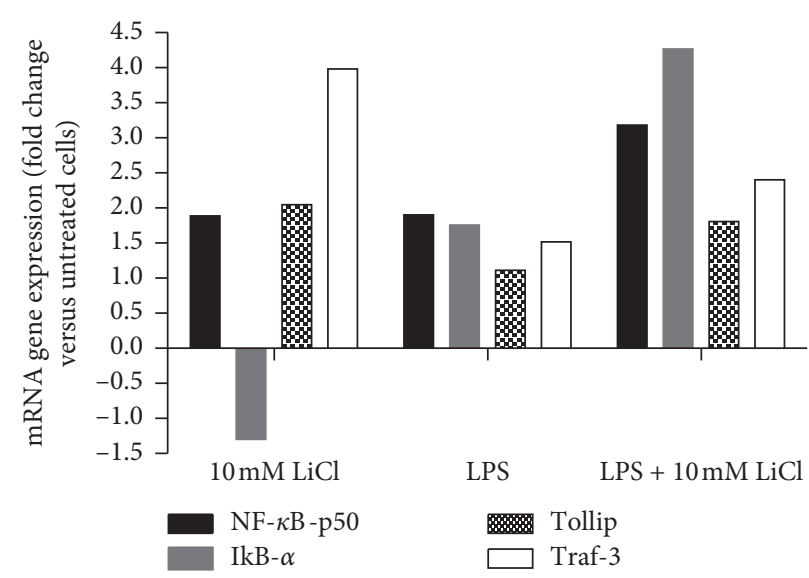

FIGURE 10: The effects of lithium on expression of NF- $\kappa$ B signalling-related genes on Raw 264.7 cells activated with LPS. Cells were cultured in $60 \mathrm{~mm}$ cell culture dishes overnight at a density of $6 \times 10^{6}$ cell $/ \mathrm{ml}$. Thereafter, cells were treated with $10 \mathrm{mM}$ lithium, $10 \mu \mathrm{m} / \mathrm{ml} \mathrm{LPS}$, and a combination of lithium and LPS for $24 \mathrm{hrs}$. Total RNA isolation was accomplished with Qiagen Total RNA isolation kit; cDNA was synthesised with $\mathrm{RT}^{2}$ first-strand kit. $\mathrm{RT}^{2}$ profiler PCR arrays were used to measure the expression profiles of NF- $\kappa \mathrm{B}$ in which 40 cycles were accomplished, 1 cycle for $10 \mathrm{~min}$ at $95^{\circ} \mathrm{C}$ and 40 cycles of $15 \mathrm{~s}$ at $95^{\circ} \mathrm{C}$ and $1 \mathrm{~min}$ at $60^{\circ} \mathrm{C}$. Thereafter, Qiagen web-based data analysis was used to analyse the $C_{\mathrm{t}}$ values and then GraphPad Prism 4 was used to plot the graphs.

colour that embodies $\mathrm{NO}_{2}{ }^{-}$as compared to LPS-activated cells during Griess assay (Figure 6). Evaluation of NO production was further pursued using florigenic cell permeants and NO indicator, DAF2-DA, which fluoresces green upon interaction with NO. Lithium concentrations of up to $5 \mathrm{mM}$ showed low DAF fluorescence intensity, which represents low production of NO (Figures $7(\mathrm{a})$ and $7(\mathrm{~b})$ ). Lower concentrations of lithium seem to have a profound inhibitory effect on NO production in LPS-activated macrophages; this could be as a result of the previous suggested narrow activity spectrum of lithium [2]. Many studies investigating the effect of lithium on $\mathrm{NO}$ production reported inconsistent findings dependent on cell type and nature of experimental setup. Several studies reported that lithium enhances NO production whereas others showed that lithium inhibits the NO pathways. Other studies reported no significant changes in NO production patterns of cells treated with lithium $[14,33,34]$.

There seems to be more to lithium than its successful use in the management of bipolar disorders. Results from this study and other recent findings point towards the potential use of lithium in the management of neurodegenerative disorders [14]. Its neuroprotective property is suggested to emanate from suppression of proapoptotic proteins such as p53 and activation of antiapoptotic proteins such as Bcl-2, heat shock protein-40 and modulation of PI3K/Akt survival signalling pathway [2]. Lithium has played a significant role in psychiatry for more than 60 years as a gold standard mood stabilizer with desirable outcomes $[1,35]$. In addition to its pivotal role in manic ailments, studied have shown its great involvement in inflammation. It has been shown to ameliorate multiple sclerosis through attenuation of proinflammatory cytokines, leukocyte infiltration through endothelial barrier, and inactivating the microglia cells activity that is known to be causative of neuronal cells demyelination [36]. Moreover, Wang and colleagues have recognised attenuation of type I interferon both in vivo and in vitro after challenging cells and mice with Sendai virus $(\mathrm{seV})$. Interestingly, mice treated with lithium did not develop severe leukocyte extravasation or any tissue damage signs as recognised in lithium-untreated mice [20].

Although extensive research has been done towards the possible use of lithium as a potential anti-inflammatory agent, the exact mechanism of lithium remains unknown and molecular targets associated with its observed outcomes remains unclear. Most research about lithium focused on its effects in neuropsychiatric models or cells associated with the central nervous system (e.g., microglia, astrocytes, and oligodendrocytes) and various molecular targets in this area have been studied [14]. Limited research has focused on the effects of lithium in innate immunity by studying its effects on mammalian macrophages. It was, therefore, the intention of this study to provide more information on molecular targets of lithium by evaluating the effect of lithium on NF- $\kappa$ B activity and mRNA expression levels of genes associated with regulation of oxidative stress and inflammation in a nonneuronal model of Raw 264.7 macrophages so as to further understand its actions beyond bipolar disorders. Interestingly, other studies have reported that lithium appears to preserve or increase the volume of brain structures involved in emotional regulation such as the prefrontal cortex, hippocampus, and amygdala, possibly reflecting its neuroprotective effects on neuronal and noncancerous mammalian cells [37].

Various cytotoxicity and apoptosis assays were used in this study to confirm that lithium does not induce cell death in the Raw 264.7 macrophage cells (Figures 1-4). The results are in agreement with previous findings showing the selective cytotoxic effect of lithium on cancerous cells while sparing their noncancerous counterparts [24, 38-40]. Moreover, this work supports the reliable safe use of lithium in clinical health and its hematopoietic role [41, 42]. Unlike other reports from studies that used neuronal cells and neuronal macrophages, 


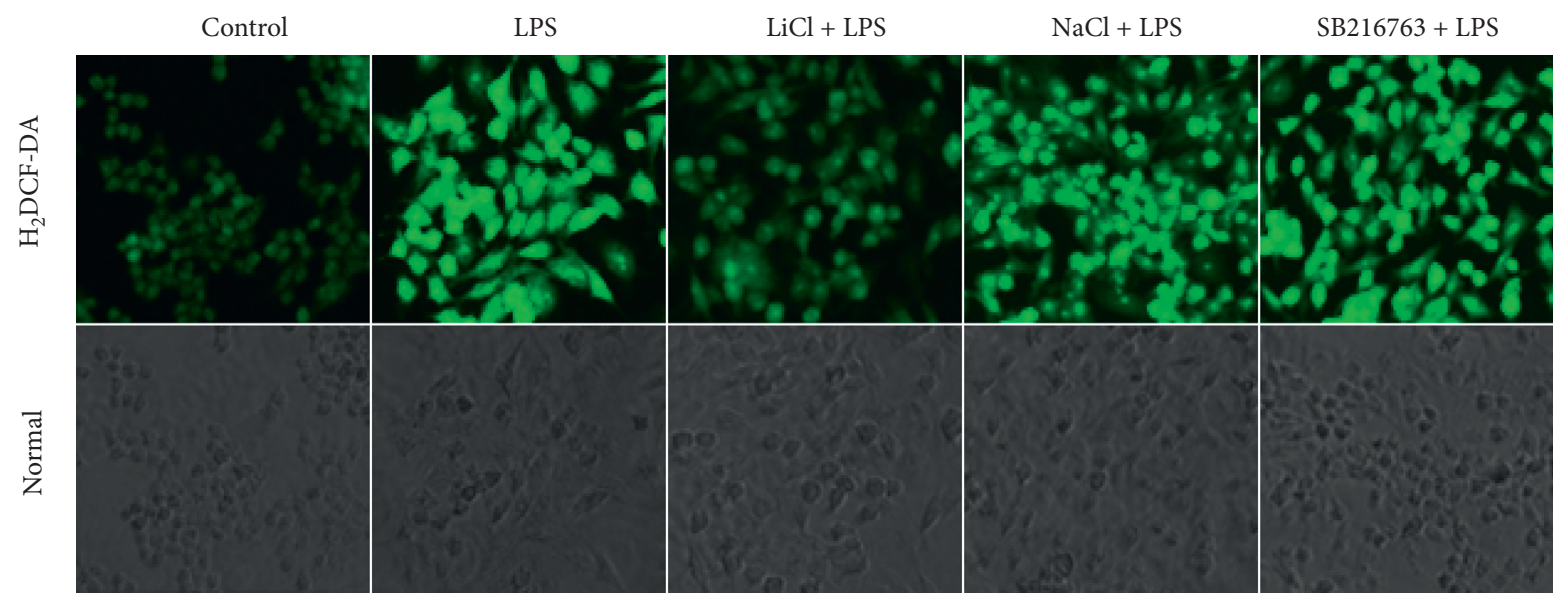

(a)

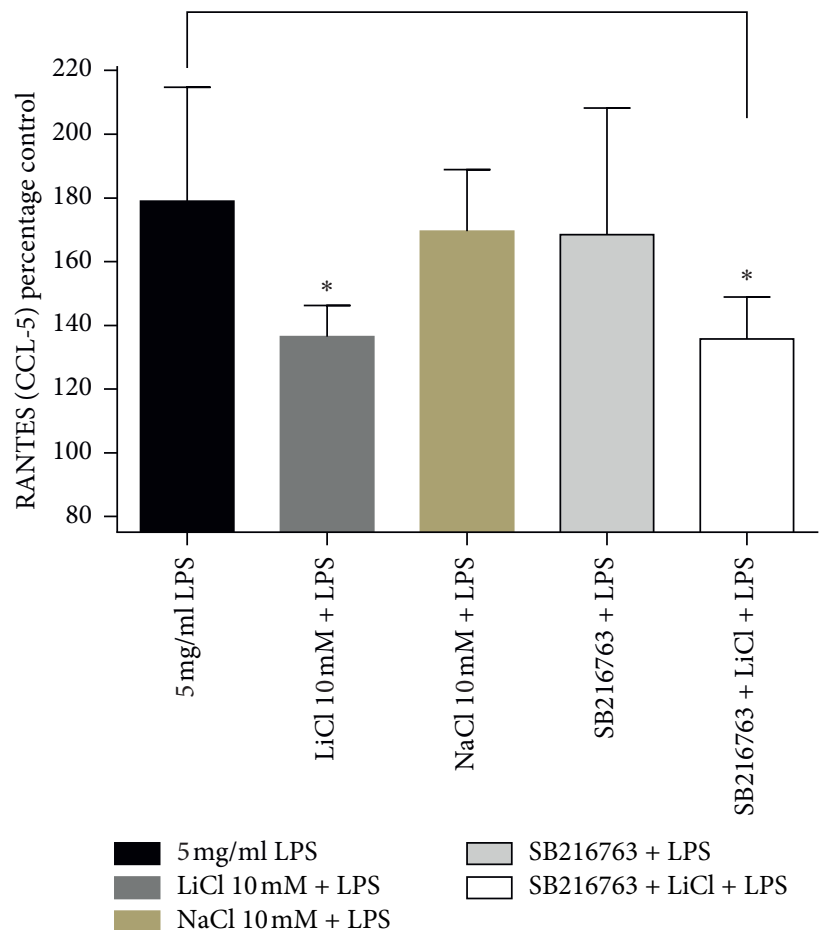

(b)

FIGURE 11: Effects of GSK3 $\beta$ inhibitors (lithium and SB216763) as mechanism of inflammation inhibition. Cells were seeded at $6 \times 10^{5}$ cells/ $\mathrm{ml}(200 \mu \mathrm{l})$ on a coverslip and pretreated with $10 \mathrm{mM}$ lithium/sodium chloride and activated with $5 \mathrm{mg} / \mathrm{ml}$ LPS for $24 \mathrm{hrs}$. The fluorescence measurement was captured at 20x magnification with EVOS FL Colour imaging system (Life technologies, USA). B measurement of the CCL-5 chemokine was executed by seeding cell at $6 \times 10^{6}$ cells $/ \mathrm{ml}$ in T25 flask overnight, followed by treatment of cells with lithium as outlined above and activated with $5 \mathrm{mg} / \mathrm{ml}$ LPS for $24 \mathrm{hrs}$. The levels of RANTES/CCL-5 in the supernatant were measured with Elisa assay $24 \mathrm{hrs}$ after treatment and stimulation. The graphs were executed using GraphPad Prism 4 software and the statistical analysis was carried out with GraphPad InStat software using ANOVA (Tukey-Kramer) $\left({ }^{*} p<0.05 ;{ }^{* * *} p<0.001\right)$. 


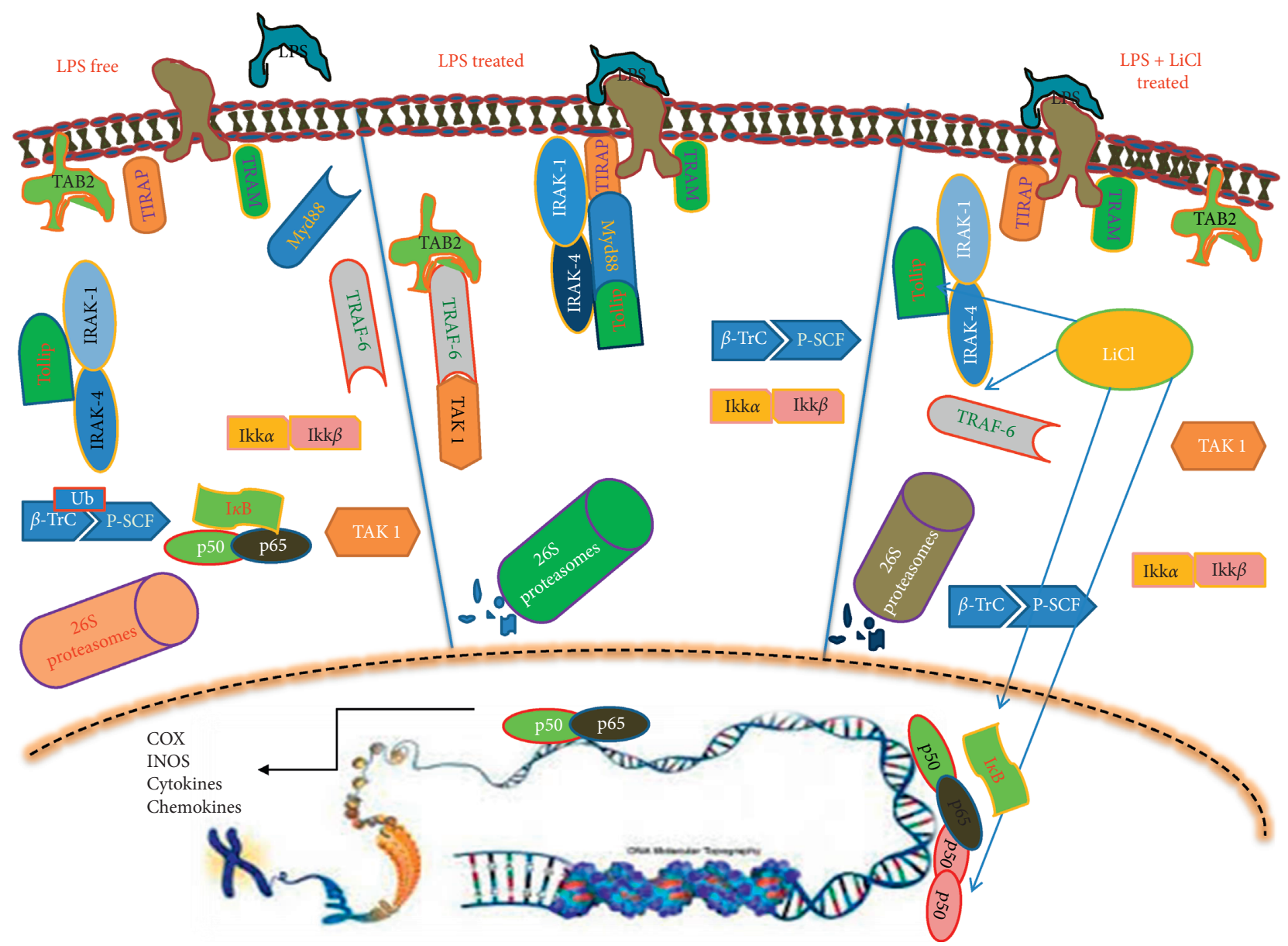

FIGURE 12: Demonstration of the putative mechanism of action of lithium in the NF- $\kappa$ B signalling pathway. The LPS free signalling involves the inhibition of the IRAK proteins in the cytoplasm by Tollip protein; this molecule is known to arrest immune cells in quiescent state in the absence of infection or stimulant. Thus, the inhibition of the IRAK proteins leads to the integrity of $\mathrm{I} \kappa \mathrm{B}$; then the entire signalling pathway is inhibited. In the LPS treatment, the adapter molecule (Myd88) is recruited to the receptor; this then recruits the IRAK proteins in association with Tollip protein. Therefore, the IRAK protein phosphorylates TRAF protein which recruits the TAB2 and TAK 1 which phosphorylates activated IKK. The IKK then phosphorylates $\mathrm{I} \kappa \mathrm{B}$; this molecule is then tagged for degradation by a ubiquitin. This sequence sequesters the $\mathrm{NF}-\kappa \mathrm{B}$ in the nucleus leading to the expression of inflammatory genes. The combinatory treatment that includes lithium chloride and LPS is thought to disturb the signalling pathway since lithium showed expression of some inhibitory proteins such as p50, I $\kappa \mathrm{B}-\alpha$, NF- $\kappa \mathrm{B}$, and Tollip (shown by arrows). These inhibitory molecules are the control points of the NF- $\kappa$ B signalling pathway. Overexpression of Tollip protein is thought to disturb the pathway by arresting the IRAK protein and then I $\kappa \mathrm{B}-\alpha$ removes the NF- $\kappa \mathrm{B}$ from its responsive element by its DNA dissociation ability. Moreover, the p50 homodimer competes for the responsive element with the NF- $\kappa \mathrm{B}$ p50-p65 heterodimer.

our findings show the effects of lithium and LPS on proliferation of nonneuronal macrophages in real time while observing accompanying changes in oxidative stress levels. These cellular profiles of lithium which correlated with reduced oxidative stress also support research findings obtained using mammalian cells of neurological origin in vitro and in vivo albeit at varying concentrations [24, 43].

\section{Conclusion}

This study is the first to show that lithium inhibits the production of reactive nitrogen and oxygen species in activated Raw 264.7 macrophages without altering cell proliferation, growth, morphology, or viability in real time while modulating mRNA expression of Tollip, Traf-3, I $\kappa \mathrm{B} \alpha$, and
NF- $\kappa \mathrm{B} 1 / \mathrm{p} 50$. It should be noted that these effects were obtained mainly under the treatment with an extratherapeutic plasma concentration (less than $1.2 \mathrm{mM}$ ) of lithium permissible in patients taking the drug, suggesting that perhaps lithium might be more effective in combination therapy to permit lower dosages with synergistic drugs. This study suggests that the anti-inflammatory mode of action of lithium involves inhibitory proteins such as p50, Tollip, TRAF3, and I $\kappa \mathrm{B}-\alpha$. The ability of lithium to exert these anti-inflammatory effects without inducing cell death in macrophages makes it a promising candidate for the treatment of inflammation-based diseases such as cancer, Alzheimer's and Parkinson's diseases, and other neurodegenerative disorders. The affordability and extensive distribution of lithium will make this type of treatment accessible to a much wider population. 


\section{Materials and Methods}

5.1. Cell Cultures. Raw 264.7 macrophage cells were obtained from Prof. Gordon Brown (Institute of Infectious Diseases and Molecular Medicines, University of Cape Town) (RSA). These cells were maintained in cell culture flasks at $37^{\circ} \mathrm{C}$, in a humidified $95 \%$ air and $5 \% \mathrm{CO}_{2}$ atmosphere. Determination of cell density was executed using trypan blue exclusion assay. This assay was accomplished by diluting cell 10x with trypan blue dye, and then the cells were counted using hemocytometer under the inverted light microscope.

5.2. xCELLigence Real-Time Cell Analyser. The real-time cell analyser system was used to evaluate cellular integrity and proliferative and cytotoxic effect of lithium on Raw 264.7 macrophage cells in real time. xCELLigence is a currentbased cell sensor that relates electrical impedance to cell status/cell index as determined by cell morphology, cell adhesion, and cell number. This system was set and initiated according to the manufacturer's protocol. Cells were seeded in microelectrical cell sensor plates at a density of 40,000 cells/well for $24 \mathrm{hrs}$ and then treated with $0.02 \mathrm{mg} / \mathrm{ml}$ actinomycin-D, $10 \mathrm{mM} \mathrm{NaCl}$, and various concentrations of lithium chloride $(1.25,2.5,5,10,20,50$, and $100 \mathrm{mM})$ for 56 hrs. The xCELLigence (RTCA) software was set to take readings after every $15 \mathrm{~min}$ interval (Roche, USA).

5.3. Cell Viability and Proliferation Assay. In order to assess proliferative and cytotoxic effects of lithium on Raw 264.7 cells, a colorimetric MTT assay that relies on the mitochondrial succinate dehydrogenase of viable cells was employed. This assay was initiated by seeding cells (Raw 264.7 macrophages) in a 96-culture-well plate at a density of $6 \times 10^{6} \mathrm{cell} / \mathrm{ml}$ and incubated overnight. Thereafter, cells were treated with various concentration of $\mathrm{LiCl}(0.6125$, $0.325,1.25,2.5,5,10,20,50$, and $100 \mathrm{mM}), 10 \mathrm{mM} \mathrm{NaCl}$, and $0.02 \mathrm{mg} / \mathrm{ml}$ actinomycin-D (Sigma Aldrich, USA) for $24 \mathrm{hr}$. Cell imaging was done using a light microscope prior to the addition of $5 \mathrm{mg} / \mathrm{ml}$ of MTT (Fluka BioChemika, Switzerland) for $4 \mathrm{hr}$. After incubation, medium was aspirated and $100 \mu \mathrm{l}$ of DMSO (Saarchem, RSA) was added to each well and the plates were incubated for an hour. This was then followed by measuring absorbance at $570 \mathrm{~nm}$ using GloMaxMulti microplate reader (Promega, USA).

5.4. Annexin-V Fluorescein-5-isothiocyanate (FITC), Propidium Iodide (PI), and (4',6-Diamidino-2-phenylindole) DAPI Apoptosis Detection Assay Using Fluorescent Microscopy. The effects of $10 \mathrm{mM}$ lithium on the induction of apoptosis in Raw 264.7 cells were assessed using Annexin-V FITC/PI kit (BD Biosciences, USA) according to the manufacturer's protocol. This assay kit detects the flipping of plasma membrane inward out, membrane integrity, and DNA fragmentation. Cells were seeded at a density of $6 \times 10^{6}$ cell/ $\mathrm{ml}$ on coverslips in six-well plates and incubated overnight. Cells were treated with $10 \mathrm{mM} \mathrm{NaCl}, 10 \mathrm{mM} \mathrm{LiCl}$, and
$0.02 \mathrm{mg} / \mathrm{ml}$ actinomycin-D for $24 \mathrm{hr}$. This was followed by the removal of medium and washing of cells with $1 \mathrm{x}$ PBS. Cells were stained with PI and Annexin-V for $20 \mathrm{~min}$ in the dark at room temperature (RT). Cells on the coverslips were fixed for $30 \mathrm{~min}$ with $3.7 \%$ paraformaldehyde. Coverslips were then mounted with mounting medium on microscope slides and photographed using Nikon Ti-E inverted fluorescent microscope (Nikon, Japan).

5.5. Annexin-V FITC and (PI) Apoptosis Detection Assay Using Flow Cytometer. Flow cytometry was used to detect and quantify LPS-activated macrophage cells undergoing apoptosis after treatment with varying concentrations of lithium. In order to examine the apoptotic effects of lithium on macrophages, cells were seeded at a density of $6 \times 10^{6}$ cell/ $\mathrm{ml}$ in $60 \mathrm{~mm}$ cell culture dishes and incubated overnight. Cells were treated with $10 \mathrm{mM} \mathrm{NaCl}, 10$ and $20 \mu \mathrm{g} / \mathrm{ml} \mathrm{ac}-$ tinomycin-D, and 5, 10, 20, and $50 \mathrm{mM} \mathrm{LiCl}$ for $24 \mathrm{hr}$. This was followed by the removal of medium and washing of cells with 1x PBS. Cells were stained with PI and Annexin-V for 20 min in the dark at RT; this was then followed by washing and suspending cells in $1 x$ PBS. Suspended cells were analysed using a flow cytometer according to the manufacturer's protocol (BD Biosciences, USA).

5.6. Griess Reagent Assay. Griess assay is a colorimetric technique that measures nitrite $\left(\mathrm{NO}_{2}^{-}\right)$, one of the two primary stable forms of nitric oxide. This assay relies on the reaction described in 1879 by Griess [16]. In order to assess the effects of lithium on nitric oxide (NO) production, cells were seeded in 96-well plates at a density of $6 \times 10^{6}$ cell/well in a phenol-free medium overnight. Cells were pretreated for 1 hour with various concentrations of lithium (5 and $10 \mathrm{mM}$ ) or $10 \mathrm{mM} \mathrm{NaCl}$ and activated with $10 \mu \mathrm{g} / \mathrm{ml} \mathrm{LPS}$ (Sigma, USA) for $24 \mathrm{hr}$. After $24 \mathrm{hr}$ of treatment, nitric oxide was measured by mixing equal amounts of phenol-free medium and Griess reagent (Sigma-Aldrich, USA). The absorbance was measured using GloMax-Multi microplate reader at $550 \mathrm{~nm}$ (Promega, USA).

5.7. DAF2-DA Nitric Oxide Measurement Assay. The DAF2DA assay is a fluorescence-based NO detection assay that uses a cell permanent 4,5-diaminofluorescein diacetate (DAF2-DA) as NO detector (Sigma-Aldrich, USA). Diacetate (DA) part of DAF2-DA is hydrolysed by cellular esterases to produce DAF2 compound that reacts with $\mathrm{NO}$ to produce a fluorescent triazolofluorescein (DAF-2T). Therefore, in this study, cells were seeded on coverslips in 6well plates overnight and then pretreated with $\mathrm{LiCl}$ ( 5 and $10 \mathrm{mM}), 10 \mathrm{mM} \mathrm{NaCl}$ and activated with $100 \mathrm{ng} / \mathrm{ml}$ Ultrapure LPS (Invitrogen, USA) for $24 \mathrm{hrs}$. Thereafter, cells were stained with $10 \mu \mathrm{m} / \mathrm{ml}$ DAF2-DA for $20 \mathrm{~min}$ at RT and washed with $1 x P B S$. Cells were further stained with $25 \mu \mathrm{g} / \mathrm{ml}$ Hoechst for $20 \mathrm{~min}$ at RT, thereafter followed by fixing with 2.7\% paraformaldehyde for $30 \mathrm{~min}$. Nitric oxide quantitation was accomplished using a Nikon Ti-E inverted fluorescent microscope (Nikon, Japan). 
TABLE 1: NF $\kappa$ B pathway gene table with accession numbers of the primer genes used in the profiler real-time PCR array assay in LPSactivated Raw 264.7 macrophages.

\begin{tabular}{|c|c|c|c|}
\hline $\begin{array}{l}\text { NF- } \kappa \text { B pathway associated } \\
\text { gene }\end{array}$ & Description & UniGene & GeneBank \\
\hline Tollip & Toll interacting protein & Mm.103551 & NM_023764 \\
\hline Traf3 & TNF receptor-associated factor 3 & Mm.27431 & NM_011632 \\
\hline $\mathrm{NF}-\kappa \mathrm{Bia} / \mathrm{I} \kappa \mathrm{B}-\alpha$ & $\begin{array}{c}\text { Nuclear factor of kappa light polypeptide gene enhancer in B-cells inhibitor, } \\
\text { alpha }\end{array}$ & Mm.170515 & NM_010907 \\
\hline $\mathrm{NF}-\kappa \mathrm{B} 1 / \mathrm{p} 50$ & Nuclear factor of kappa light polypeptide gene enhancer in B-cells 1, p105 & Mm.256765 & NM_008689 \\
\hline
\end{tabular}

5.8. Oxidative Burst Assay. In an attempt to analyse the effects of lithium on oxidative burst, a Phagoburst assay kit (Glycotope, Germany) was employed and the oxidative burst assays were performed according to the manufacturer's protocol. This is a fluorescence-based assay that uses a florigenic cell permeant, $\mathrm{H}_{2}$ DCF-DA, that is converted to a highly fluorescent DCF through the removal of the acetate groups by intracellular esterases and subsequent oxidation. In summary, cells were seeded at a density of $6 \times 10^{6} \mathrm{cell} / \mathrm{ml}$ on coverslips in 6 -well plates overnight. Adherent cells were then pretreated with $10 \mathrm{mM} \mathrm{LiCl}$ and activated with $10 \mu \mathrm{g} / \mathrm{ml}$ LPS for $24 \mathrm{hr}$. Thereafter, the cells were washed once with a wash buffer and $50 \mu \mathrm{l}$ of $\mathrm{H}_{2}$ DCFDA was added in all plates followed by a $30 \mathrm{~min}$ incubation in the dark at RT. Cells were then washed with a washing solution to remove excess dye and $50 \mu \mathrm{l}$ of DNA staining solution was added. Cells were incubated with DNA staining solution for $20 \mathrm{~min}$ at RT in the dark. DNA staining solution was then removed, and 3.7\% paraformaldehyde was added for $30 \mathrm{~min}$ to fix the cells. This was followed by mounting of coverslips to the microscope and examination. On the second $\mathrm{H}_{2} \mathrm{DCF}-\mathrm{DA}$ assay, the assay was the same as the first one with the addition of $10 \mu \mathrm{M}$ SB216763, which was used to treat the cells and then stimulated with $5 \mathrm{mg} / \mathrm{ml} \mathrm{LPS.} \mathrm{Then,}$ fluorescence intensity was measured at 20x magnification with EVOS FL Colour imaging system (Life Technologies, USA).

5.9. Immunocytochemistry. Translocation properties of NF$\kappa \mathrm{B}$ will be assessed by immunofluorescence staining technique. Cells were cultured at a density of $6 \times 10^{5}$ cells $/ \mathrm{ml}$ on coverslips and allowed to adhere for $4 \mathrm{hrs}$. Thereafter, cells were treated with $10 \mathrm{mM} \mathrm{LiCl}, 10 \mathrm{mM} \mathrm{NaCl}, 100 \mathrm{ng} / \mathrm{ml}$ ultrapure LPS, and a combination of salts and LPS for 90 min. Cells were then washed with 1x PBS and fixed at RT for $30 \mathrm{~min}$ with $3.7 \%$ paraformaldehyde. Thereafter, cells were washed with 1x PBS and permeabilised with a permeabilising buffer $(0.1 \%$ Triton X-100, $1 \%$ BSA in $1 x$ PBS) for $30 \mathrm{~min}$. The nonspecific binding was blocked with $1 \%$ BSA in 1x PBS for an hour. Thereafter, cells were incubated with anti-NF-kB antibody (1:500) for an hour, and then the cells were washed $3 \mathrm{x}$ with $1 \mathrm{x}$ PBS and stained for $30 \mathrm{~min}$ with anti-rabbit IgG-fluorescence $(1: 2000)$. After $30 \mathrm{~min}$ incubation, cells were washed with 1x PBS and then followed by DNA staining with $25 \mu \mathrm{g} / \mathrm{ml}$ Hoechst for $20 \mathrm{~min}$ at RT. Thereafter, coverslips were mounted on glass slides with mounting medium and then NF- $\kappa \mathrm{B}$ translocation was analysed under fluorescence microscope (Nikon Eclipse TS100F, Japan).
5.10. Elisa Assay RANTES Production Determination. In order to measure the production of RANTES/CCL-5, Raw 264.7 cells were seeded at $1 \times 10^{6}$ Cells for $24 \mathrm{hrs}$ in T25 flasks and then cells were treated with $10 \mathrm{mM} \mathrm{LiCl}, \mathrm{NaCl}$, and $10 \mu \mathrm{M}$ SB216763, thereafter activated with $5 \mathrm{mg} / \mathrm{ml}$ LPS for $24 \mathrm{hrs}$. The supernatant was collected after $24 \mathrm{hrs}$, and then enzyme-linked immunosorbent assay (ELISA) was executed according to the manufacturer's protocol (PeproTech, USA). The OD was measured at $405 \mathrm{~nm}$ with ELx 802 universal microplate reader (BioTek Instruments, Inc.).

5.11. Real-Time PCR Analysis. Raw 264.7 cells were cultured in a $60 \mathrm{~mm}$ cell culture dishes overnight at a density of $6 \times 10^{6} \mathrm{cell} / \mathrm{ml}$. Thereafter, cells were treated with $10 \mathrm{mM}$ $\mathrm{LiCl}, 10 \mu \mathrm{m} / \mathrm{ml} \mathrm{LPS}$, and a combination of $10 \mathrm{mM} \mathrm{LiCl}$ and $10 \mu \mathrm{m} / \mathrm{ml}$ LPS for $24 \mathrm{hrs}$. Total RNA was isolated using RNeasy Mini Kit according to the manufacturer's procedure (Qiagen, USA) and then cDNA was synthesised as specified by $\mathrm{RT}^{2}$ first-strand kit manufacturer's protocol (Qiagen, USA). In order to analyse gene expression in each sample, a 96-well RT ${ }^{2}$ profiling PCR Array system was used; accession numbers of target genes are specified in Table 1 . A reaction mixture composed of $1350 \mu \mathrm{l}$ mixture of $2 \mathrm{x} \mathrm{RT}^{2}$ SYBR Green Master Mix, $102 \mu \mathrm{l}$ cDNA synthesis reaction, and RNase-free water was formulated. Prior to the addition of PCR components mixture, the array plates were briefly centrifuged at low speed. Twenty-five microliters of PCR components mixture was added to each well of $\mathrm{RT}^{2}$ profiling PCR arrays coated with different target primers and the $\mathrm{RT}^{2}$ profiling PCR arrays were tightly sealed with optical thin-wall 8 strips. Before cycling, the arrays were briefly centrifuged at $1000 \times \mathrm{g}$ for $1 \mathrm{~min}$ at $25^{\circ} \mathrm{C}$. Thereafter, 40 cycles were prepared; 1 cycle for $10 \mathrm{~min}$ at $95^{\circ} \mathrm{C}, 40$ cycles of $15 \mathrm{~s}$ at $95^{\circ} \mathrm{C}$, and $1 \mathrm{~min}$ cycle at $60^{\circ} \mathrm{C}$.

\section{Abbreviations}

FDA: $\quad$ Food and Drug Administration

MØ: $\quad$ Macrophages

LPS: $\quad$ Lipopolysaccharide

H2DCF-DA: $2^{\prime}, 7^{\prime}$-Dichlorodihydrofluorescein diacetate

RHD: Rel homology domain

PSN: $\quad$ Penicillin, streptomycin, and neomycin

FBS: $\quad$ Fetal bovine serum

DAF-2DA: 5, 6-Diaminofluorescein diacetate

ROS: $\quad$ Reactive oxygen species

NO: $\quad$ Nitric oxide 


$\begin{array}{ll}\mathrm{NO}_{2}{ }^{-}: & \text {Nitrite } \\ \text { MTT: } & \begin{array}{l}\text { 3-(4, 5-Dimethylthiazol-2-yl)-2, 5- } \\ \text { diphenyltetrazolium bromide }\end{array} \\ \text { GSK-3: } & \text { Glycogen synthase kinase-3 } \\ \text { NF- } \kappa \text { B: } & \text { Nuclear factor- } \kappa \mathrm{B} \\ \text { I } \kappa \text { B- } \alpha: & \text { Inhibitor of kappa-B kinase alpha } \\ \text { TRAF3: } & \text { TNF receptor-associated factor 3 } \\ \text { Tollip: } & \text { Toll interacting protein } \\ \text { Tcf-Lef: } & \text { T-cell factor-lymphoid enhancing factor } \\ \gamma \text {-GCS: } & \gamma \text {-Glutamylcysteine synthetase } \\ \text { PI3K: } & \text { Phosphoinositol 3-kinase } \\ \text { p53: } & \text { Tumor suppressor. }\end{array}$

\section{Data Availability}

The raw data are available from the corresponding author upon reasonable request.

\section{Conflicts of Interest}

The authors declare that there are no conflicts of interest regarding the publication of this work.

\section{Authors' Contributions}

Raymond T. Makola and Vusi G. Mbazima carried out the planning and execution of the experiments. Matlou P. Mokgotho proofread the manuscript, while Vincent S. Gallicchio and Thabe M. Matsebatlela conceptualized the idea and analysed the results. This manuscript was written by Raymond T. Makola.

\section{Acknowledgments}

The authors thank Prof. Gordon Brown for the Raw 264.7 cell lines and Miss Carol Pilane for her support and assistance with using the xCELLigence RTCA (Roche) instrument. This work was supported by the National Research Foundation (NRF) of South Africa, Medical Research Foundation, and the University of Limpopo Research and Development. The grants were awarded to Prof. Thabe M. Matsebatlela.

\section{References}

[1] J. F. J. Cade, "Lithium salts in the treatment of psychotic excitement," Medical Journal of Australia, vol. 2, no. 10, pp. 349-352, 1949.

[2] E. Y. Plotnikov, D. N. Silachev, L. D. Zorova et al., "Lithium salts-simple but magic," Biochemistry (Moscow), vol. 79, no. 8, pp. 932-943, 2014.

[3] A. Strunecká, J. Patočka, and M. Šárek, "How does lithium mediate its therapeutic effects?" Journal of Applied Biomedicine, vol. 3, no. 1, pp. 25-35, 2005.

[4] L. Freland and J. M. Beaulieu, "Inhibition of GSK3 by lithium, from single molecules to signalling networks," Frontiers in Molecular Neuroscience, vol. 5, pp. 1-7, 2012.

[5] R. S. B. Williams and A. J. Harwood, "Lithium therapy and signal transduction," Trends in Pharmacological Sciences, vol. 21, no. 2, pp. 61-64, 2000.
[6] J. A. Quiroz, T. D. Gould, and H. K. Manji, "Molecular effects of lithium,” Molecular Interventions, vol. 4, no. 5, pp. 259-272, 2004.

[7] S. Reuter, S. C. Gupta, M. M. Chaturvedi, and B. B. Aggarwal, "Oxidative stress, inflammation, and cancer: how are they linked?" Free Radical Biology and Medicine, vol. 49, no. 11, pp. 1603-1616, 2010.

[8] T. A. Wynn, A. Chawla, and J. W. Pollard, "Macrophage biology in development, homeostasis and disease," Nature, vol. 496, no. 7446, pp. 445-455, 2013.

[9] R. S. Jope, C. J. Yuskaitis, and E. Beurel, "Glycogen synthase kinase-3 (GSK3): inflammation, diseases, and therapeutics," Neurochemical Research, vol. 32, no. 4-5, pp. 577-595, 2007.

[10] P. J. Barnes and M. Karin, "Nuclear factor- $\kappa$ B - a pivotal transcription factor in chronic inflammatory diseases," New England Journal of Medicine, vol. 336, no. 15, pp. 1066-1071, 1997.

[11] Q. Li, H. Li, K. Roughton et al., "Lithium reduces apoptosis and autophagy after neonatal hypoxia-ischemia," Cell Death \& Disease, vol. 1, no. 7, pp. 2041-4889, 2010.

[12] R. H. Lenox and L. Wang, "Molecular basis of lithium action: integration of lithium-responsive signaling and gene expression networks," Molecular Psychiatry, vol. 8, no. 2, pp. 135-144, 2003.

[13] J. G. Pizarro, M. Yeste-Velasco, V. Rimbau et al., "Neuroprotective effects of SB-415286 on hydrogen peroxide-induced cell death in B65 rat neuroblastoma cells and neurons," International Journal of Developmental Neuroscience, vol. 26, no. 3-4, pp. 269-276, 2008.

[14] A. Nassar and A. N. Azab, "Effects of lithium on inflammation," ACS Chemical Neuroscience, vol. 5, no. 6, pp. 451-458, 2014.

[15] M. Hull, E. Lee, T. Lee, N. Anand, V. LaLone, and N. Parameswaran, "Lithium chloride induces TNF $\alpha$ in mouse macrophages via MEK-ERK-dependent pathway," Journal of Cellular Biochemistry, vol. 115, no. 1, pp. 71-80, 2014.

[16] P. Griess, "Bemerkungen zu der abhandlung der HH. weselsky und benedikt "ueber einige azoverbindungen"," Berichte der deutschen chemischen Gesellschaft, vol. 12, no. 1, pp. 426-428, 1879.

[17] D. A. E. Cross, A. A. Culbert, K. A. Chalmers, L. Facci, S. D. Skaper, and A. D. Reith, "Selective small-molecule inhibitors of glycogen synthase kinase- 3 activity protect primary neurones from death," Journal of Neurochemistry, vol. 77, no. 1, pp. 94-102, 2001.

[18] B. Marchand, D. Arsenault, A. Raymond-Fleury, F.-M. Boisvert, and M.-J. Boucher, "Glycogen synthase kinase-3 (GSK3) inhibition induces prosurvival autophagic signals in human pancreatic cancer cells," Journal of Biological Chemistry, vol. 290, no. 9, pp. 5592-5605, 2015.

[19] S. Kim, Y. Joe, H. J. Kim et al., "Endoplasmic reticulum stressinduced IRE $1 \alpha$ activation mediates cross-talk of GSK-3 $\beta$ and XBP-1 to regulate inflammatory cytokine production," The Journal of Immunology, vol. 194, no. 9, pp. 4498-4506, 2015.

[20] L. Wang, L. Zhang, X. Zhao, M. Zhang, W. Zhao, and C. Gao, "Lithium attenuates IFN- $\beta$ production and antiviral response via inhibition of TANK-binding kinase 1 kinase activity," The Journal of Immunology, vol. 191, no. 8, pp. 4392-4398, 2013.

[21] P. Clement-Lacroix, M. Ai, F. Morvan et al., "Lrp5-independent activation of wnt signaling by lithium chloride increases bone formation and bone mass in mice," Proceedings of the National Academy of Sciences, vol. 102, no. 48, pp. 17406-17411, 2005.

[22] C. E. Hartley, A. Buchan, S. Randall, G. R. B. Skinner, M. Osborne, and L. M. Tomkins, "The effects of lithium and 
potassium on macromolecular synthesis in herpes simplex virus-infected cells," Journal of General Virology, vol. 74, no. 8, pp. 1519-1525, 1993.

[23] B. Sproule, "Lithium in bipolar disorder can drug concentrations predict therapeutic effect?" Clinical Pharmacokinetics, vol. 41, no. 9, pp. 639-660, 2002.

[24] S. Nahman, R. Belmaker, and A. N. Azab, "Effects of lithium on lipopolysaccharide-induced inflammation in rat primary glia cells," Innate Immunity, vol. 18, no. 3, pp. 447-458, 2011.

[25] M. O. Nowicki, N. Dmitrieva, A. M. Stein et al., "Lithium inhibits invasion of glioma cells; possible involvement of glycogen synthase kinase-3," Neuro-Oncology, vol. 10, no. 5, pp. 690-699, 2008.

[26] C. L. Thompson, H. Yasmin, A. Varone, A. Wiles, A. C. Poole, and M. M. Knight, "Lithium Chloride Prevents Interleukin-1b Induced Cartilage," Journal of Orthopaedic Research, vol. 33, no. 10, pp. 1552-1559, 2015.

[27] A. Didierlaurent, B. Brissoni, D. Velin et al., “Tollip regulates proinflammatory responses to interleukin-1 and lipopolysaccharide," Molecular and Cellular Biology, vol. 26, no. 3, pp. 735-742, 2006.

[28] M. Khasraw, D. Ashley, G. Wheeler, and M. Berk, "Using lithium as a neuroprotective agent in patients with cancer," BMC Medicine, vol. 10, pp. 131-137, 2012.

[29] R. W. Becker and E. M. Tyobeka, "Lithium enhances the proliferation of HL-60 promyelocytic leukemia cells," Leukemia Research, vol. 14, no. 10, pp. 879-884, 1990.

[30] M. S. Hayden and S. Ghosh, "NF- B, the first quarter-century: remarkable progress and outstanding questions," Genes \& Development, vol. 26, no. 3, pp. 203-234, 2012.

[31] I. A. Udalova, A. Richardson, A. Denys et al., "Functional consequences of a polymorphism affecting NF- $\kappa$ B p50-p50 binding to the TNF promoter region," Molecular and Cellular Biology, vol. 20, no. 24, pp. 9113-9119, 2000.

[32] M. Lechner, P. Lirk, and J. Rieder, "Inducible nitric oxide synthase (iNOS) in tumor biology: the two sides of the same coin," Seminars in Cancer Biology, vol. 15, no. 4, pp. 277-289, 2005.

[33] S. Maruta, E. Suzuki, M. Yokoyama et al., "Effects of intraperitoneally injected lithium, imipramine and diazepam on nitrate levels in rat amygdala," Psychiatry and Clinical Neurosciences, vol. 59, no. 3, pp. 358-361, 2005.

[34] D. L. Feinstein, "Potentiation of astroglial nitric oxide synthase type-2 expression by lithium chloride," Journal of Neurochemistry, vol. 71, no. 2, pp. 883-886, 1998.

[35] G. McKellar, R. Madhok, and G. Singh, "The problem with NSAIDs: what data to believe?" Current Pain and Headache Reports, vol. 11, no. 6, pp. 423-427, 2007.

[36] P. De Sarno, R. C. Axtell, C. Raman, K. A. Roth, D. R. Alessi, and R. S. Jope, "Lithium prevents and ameliorates experimental autoimmune encephalomyelitis," The Journal of Immunology, vol. 181, no. 1, pp. 338-345, 2008.

[37] G. S. Malhi, M. Tanious, P. Das, C. M. Coulston, and M. Berk, "Potential mechanisms of action of lithium in bipolar disorder: current understanding," CNS Drugs, vol. 27, no. 2, pp. 135-153, 2013.

[38] T. M. Matsebatlela, R. K. Mogodiri, D. A. Hart, V. S. Gallicchio, and R. W. Becker, "Resistance to lithiuminduced apoptosis in a lithium tolerant clone of HL-6 promyelocytes," Journal of Trace and Microprobe Techniques, vol. 18, pp. 163-170, 2000.

[39] L. J. Mampuru, E. K. Abotsi, and S. J. M. Wachira, "CalyculinA potentiates growth and apoptotic effects of lithium in HL-
60 cells," Journal of Trace and Microprobe Techniques, vol. 17, pp. 367-378, 1999.

[40] T. Matsebatlela, V. Gallicchio, and R. Becker, "Lithium modulates cancer cell growth, apoptosis, gene expression and cytokine production in HL-60 promyelocytic leukaemia cells and their drug-resistant sub-clones," Biological Trace Element Research, vol. 149, no. 3, pp. 323-330, 2012.

[41] V. S. Gallicchio, N. K. Hughes, and K. F. Tse, "Modulation of the haematopoietic toxicity associated with zidovudinein vivowith lithium carbonate," Journal of Internal Medicine, vol. 233, no. 3, pp. 259-268, 1993.

[42] V. S. Gallicchio, M. J. Messino, B. C. Hulette, and N. K. Hughes, "Lithium and hematopoiesis: effective experimental use of lithium as an agent to improve bone marrow transplantation," Journal of Medicine, vol. 23, no. 3-4, pp. 195-216, 1992.

[43] K. Kang, Y.-J. Kim, Y.-H. Kim et al., "Lithium pretreatment reduces brain injury after intracerebral hemorrhage in rats," Neurological Research, vol. 34, no. 5, pp. 447-454, 2012. 